\title{
Enhancing Dye-Sensitized Solar Cell Performances by Molecular Engineering: Highly Efficient $\pi$-Extended Organic Sensitizers
}

\author{
Roberto Grisorio, ${ }^{[\mathrm{a}]}$ Luisa De Marco, ${ }^{*[\mathrm{~b}]}$ Rita Agosta, ${ }^{[\mathrm{b}]}$ Rosabianca lacobellis, ${ }^{[\mathrm{b}, \mathrm{d}]}$ \\ Roberto Giannuzzi, ${ }^{[b]}$ Michele Manca, ${ }^{[b]}$ Piero Mastrorilli, ${ }^{[a]}$ Giuseppe Gigli, ${ }^{[b, c, d]}$ and \\ Gian Paolo Suranna*[a]
}

\begin{abstract}
This study deals with the synthesis and characterization of two $\pi$-extended organic sensitizers (G1 and G2) for applications in dye-sensitized solar cells. The materials are designed with a D$A-\pi-A$ structure constituted by i) a triarylamine group as the donor part, ii) a dithienyl-benzothiadiazole chromophore followed by iii) a further ethynylene-thiophene (G1) or ethynylene-benzene (G2) $\pi$-spacer and iv) a cyano-acrylic moiety as acceptor and anchoring part. An unusual structural extension of the $\pi$-bridge characterizes these structures. The so-configured sensitizers exhibit a broad absorption profile, the origin of which is supported by density functional theory. The absence of hypsochromic shifts as a consequence of deprotona-
\end{abstract}

tion as well as notable optical and electrochemical stabilities are also observed. Concerning the performances in devices, electrochemical impedance spectroscopy indicates that the structural modification of the $\pi$-spacer mainly increases the electron lifetime of $\mathbf{G} \mathbf{2}$ with respect to $\mathbf{G} 1$. In devices, this feature translates into a superior power conversion efficiency of G2, reaching $8.1 \%$. These results are comparable to those recorded for N719 and are higher with respect to literature congeners, supporting further structural engineering of the $\pi$ bridge extension in the search for better performing $\pi$-extended organic sensitizers.

\section{Introduction}

Fully organic sensitizers ${ }^{[1]}$ continue to capture the attention of the scientific community devoted to the development of dyesensitized solar cells (DSSC) ${ }^{[2]}$ as a competitive alternative to ruthenium(II)-based dyes. ${ }^{[3]}$ Purely organic sensitizers bring advantages in terms of availability of the starting materials, design flexibility, and higher molar absorptivity with respect to

[a] Dr. R. Grisorio, ${ }^{+}$Prof. P. Mastrorilli, Prof. G. P. Suranna DICATECh-Dipartimento di Ingegneria Civile, Ambientale, del Territorio, Edile e di Chimica

Politecnico di Bari

Via Orabona, 4 I-70125 Bari (Italy)

E-mail:surannag@poliba.it

[b] Dr. L. De Marco, ${ }^{+}$Dr. R. Agosta, Dr. R. lacobellis, Dr. R. Giannuzzi, Dr. M. Manca, Prof. G. Gigli

Center for Biomolecular Nanotechnology (CBN)

Fondazione Istituto Italiano di Tecnologia (IIT)

Via Barsanti 1, 73010, Arnesano (Italy)

E-mail: luisa.demarco@iit.it

[c] Prof. G. Gigli

NNL-Istituto Nanoscienze, CNR c/o distretto tecnologico Lecce via Arnesano 16, 73100 Lecce (Italy)

[d] Dr. R. lacobellis, Prof. G. Gigli

Department of Mathematics and Physics "E. De Giorgi"

University of Salento, Campus Universitario

via Monteroni, 73100 Lecce (Italy)

$\left.{ }^{[+}\right]$These authors contributed equally to the work.

Supporting Information for this article is available on the WWW under http://dx.doi.org/10.1002/cssc.201402164. the inorganic dyes, providing access to several possible architectures and clearing the path towards more and more efficient DSSCs. However, compared to ruthenium dyes, most organic sensitizers generally exhibit narrower absorption bands at shorter wavelengths, resulting in less effective light-harvesting. This disadvantage is related to their commonly accepted design rule (relying on the well-known $D-\pi-A$ concept) in which an electron-donating group (D) and an electron-withdrawing group (A) are connected through a suitable $\pi$-spacer $(\pi) \cdot{ }^{[4]}$ In fact, small $\pi$-bridges are usually preferred in comparison to more $\pi$-extended spacers that do increase the portion of absorbed sunlight but, at the same time, facilitate the formation of undesired aggregates ${ }^{[5]}$ and are relatively unstable when irradiated with high-energy photons. ${ }^{[6]}$ However, the formation of dye aggregates can be limited by the use of suitable co-adsorbents, ${ }^{[7]}$ although with unpredictable results in terms of device efficiency. Therefore, to further improve the performance of an organic dye, new design concepts should principally aim at achieving a broad spectral response, while at the same time preserving the optical and electrochemical stability of the molecule.

To this end, the incorporation of an electron-withdrawing unit into the $\pi$-bridge of a new generation of organic dyes (indicated as $D-A-\pi-A$ structures) can conveniently modulate the breadth of the light-harvesting range, introducing new electronic transitions with an intramolecular charge-transfer char- 
acter. ${ }^{[8]}$ Furthermore, placing an acceptor moiety within the $\pi$ bridge might lead to a remarkable improvement of the dye photo-stability by increasing its oxidation potential. ${ }^{[9]}$ Among the electron-withdrawing structures (such as benzotriazole, ${ }^{[10]}$ quinoxaline, ${ }^{[11]}$ phtalimide, ${ }^{[12]}$ or diketopyrrolopyrrole ${ }^{[13]}$ ) successfully employed for the preparation of low band-gap organic sensitizers, benzothiadiazole can certainly be considered the most widespread unit for the obtainment of high photovoltaic performance. ${ }^{[14]}$ Until now, however, little attention has been paid to the role of the $\pi$-conjugated spacer between the two acceptor units. Even a small modification of its structure could, in fact, influence both the photophysical properties of the dye and the degree of its intermolecular interactions.

Within this context, we embarked in the synthesis, characterization, and application in DSSC of the new $\pi$-extended benzothiadiazole-based structures (G1 and G2, Figure 1), aiming at evaluating the impact of the $\pi$-bridge extension of the dye on the optical properties and device performances. In particular, the synthetic design envisaged the functionalization of a dithienyl-benzothiadiazole chromophore with a suitable electron-donating triarylamine group on one side and with an ethynyl-thiophene (G1) or with an ethynyl-benzene (G2) spacer, both carrying the cyano-acrylic anchoring group, on the other side. With respect to the low band-gap $D-A-\pi-A$ sensitizer proposed by Grätzel and Kim (HKK-BTZ4, Figure 1), ${ }^{[14 g]}$ the introduction of the ethynylene-arylene spacer was motivated by its tendency to favor the electron-transfer process, ${ }^{[15]}$ promoting the planarity of the structure and the electronic communication between the donor and the acceptor parts of the molecules. Compared to G1, the apparently innocent structural modification of the $\pi$-bridge (replacement of the thiophene unit with the benzene one) resulted in a remarkable improvement of the power conversion efficiencies of DSSC devices embodying $\mathbf{G 2}$, reaching a value of $8.1 \%$ representing one of the best result thus far reported for $\pi$-extended organic sensitizers.

\section{Results and Discussion}

\section{Synthesis}

The synthetic sequence followed for the obtainment of $\mathbf{G 1}$ and G2 is illustrated in Scheme 1. A selective mono-bromination of 4,7-bis-thiophen-2-yl-benzo[2,1,3]thiadiazole was achieved with an equimolar amount of $\mathrm{N}$-bromo-succinimide (NBS) to afford the corresponding bromo-derivative 1 which, in turn, was converted into the corresponding iodo-derivative $\mathbf{2}$ by reaction with $\mathrm{N}$-iodo-succinimide (NIS). A Suzuki coupling between 4(4,4,5,5-tetramethyl-1,3,2-dioxaborolan-2-yl)- N,N-bis(4-(2-ethylhexyloxy)phenyl)-aniline and 2 allowed the binding of the triarylamine electron-donating group to the benzothiadiazole chromophore, with the obtainment of $\mathbf{3}$, endowed with the bromide leaving group. The introduction of the ethynylene moiety was accomplished by a Pd-catalyzed Sonogashira crosscoupling between 7 and trimethylsilyl-acetylene, to yield the alkyne $\mathbf{4}$. The trimethylsilyl protecting group in $\mathbf{4}$ was easily removed by reaction with potassium fluoride affording the terminal alkyne 5. At this stage, the synthetic procedure diverged for the obtainment of $\mathbf{G 1}$ and $\mathbf{G} 2$. The assembly of the $\pi$ bridges was, in fact, completed by a further Sonogashira crosscoupling of $\mathbf{5}$ with either 5-bromo-thiophene-2-carbaldehyde or with 4-bromobenzaldehyde to obtain aldehydes 6 and 7, respectively. The introduction of the cyano-acrylic functionality was carried out subjecting 6 and $\mathbf{7}$ to a Knoevenagel condensation with cyanoacetic acid in the presence of ammonium acetate eventually yielding the target molecules $\mathbf{G} 1$ and $\mathbf{G} 2$, respectively. The chemical structures of the dyes as well as those of their precursors were confirmed by a combination of elemental analysis, multinuclear NMR spectroscopy, IR spectroscopy, and mass spectrometry.

\section{Photophysical and electrochemical properties}

The UV/Vis absorption spectra of G1 and G2 measured in THF are shown in Figure S1A, Supporting Information. The absorp-
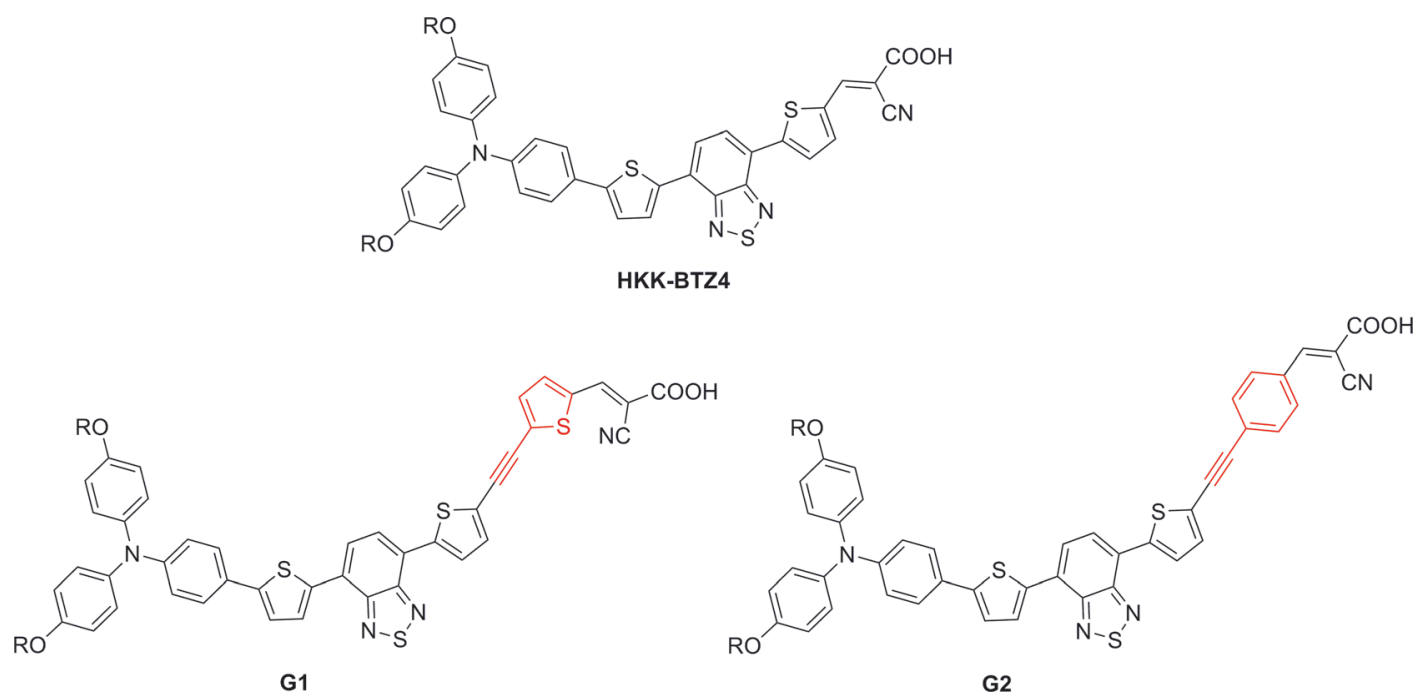

Figure 1. Chemical structure of G1, G2, and the congener HKK-BTZ4 (R=2-ethyl-hexyl). 

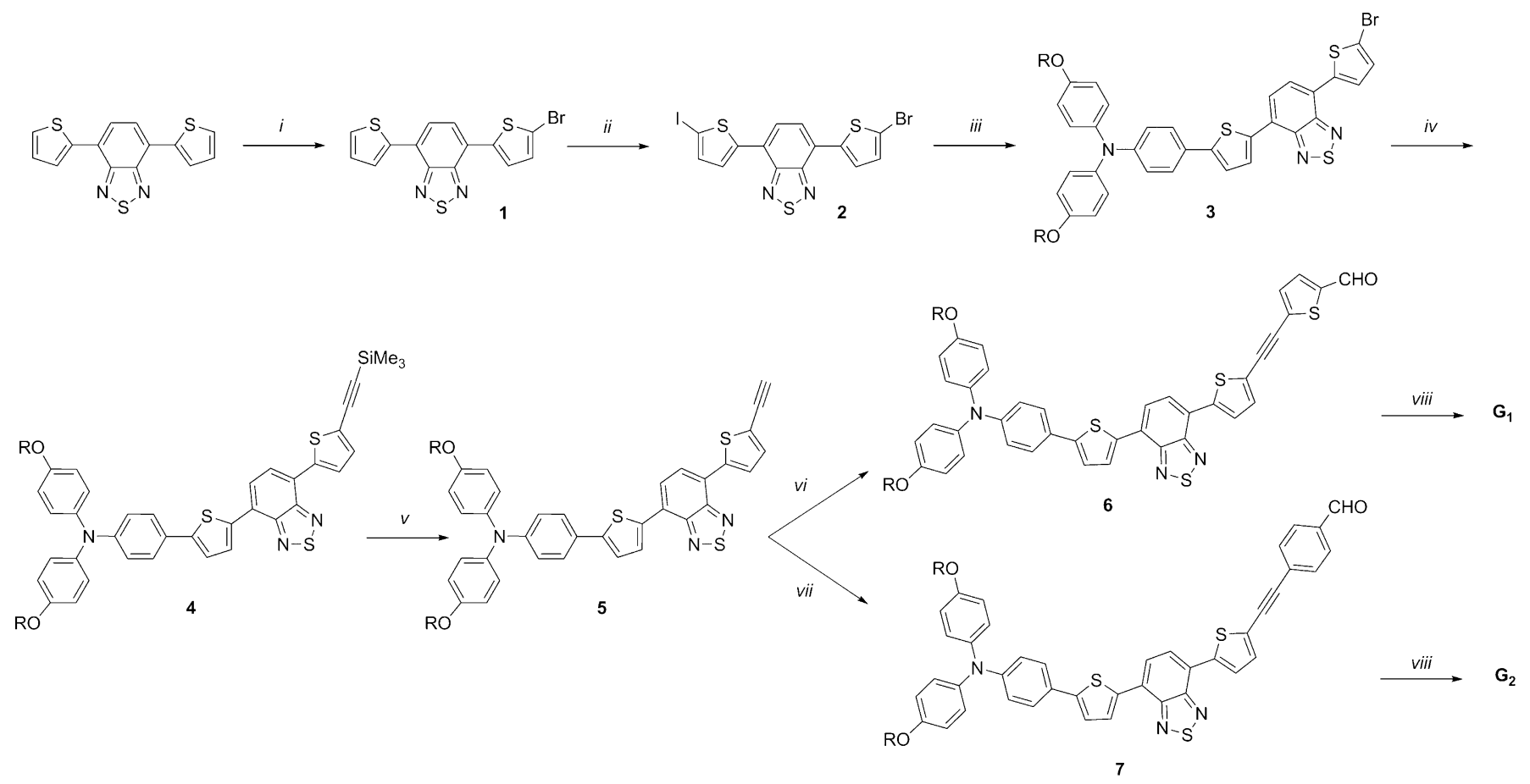

Scheme 1. Synthetic sequence for the obtainment of G1 and G2. i: NBS, DMF, $0^{\circ} \mathrm{C}(35 \%)$; ii: $\mathrm{NIS}_{2} \mathrm{CH}_{2} \mathrm{Cl}_{2}, \mathrm{CH}_{3} \mathrm{COOH}, \mathrm{rt}(62 \%)$; iii: 4-(4,4,5,5-tetramethyl-1,3,2-dioxaborolan-2-yl)- $\mathrm{N}, \mathrm{N}$-bis(4-(2-ethyl-hexyloxy)phenyl)-aniline (1 equiv), $\mathrm{Pd}\left(\mathrm{PPh}_{3}\right)_{4}, \mathrm{THF}, 1 \mathrm{M} \mathrm{NaHCO}$, reflux (74\%); iv: trimethylsilyl-acetylene, $\mathrm{PdCl}(\mathrm{PPh})_{2}, \mathrm{Cul}$,

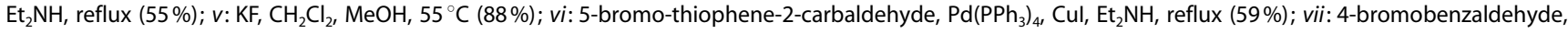
$\mathrm{Pd}\left(\mathrm{PPh}_{3}\right)_{4}, \mathrm{Cul}, \mathrm{Et}_{2} \mathrm{NH}$, reflux (53\%); viii: cyano-acetic acid, $\mathrm{CH}_{3} \mathrm{COONH}_{4}, \mathrm{CH}_{3} \mathrm{COOH}$, reflux; yield: $40 \%(\mathrm{G1})$ and $38 \%(\mathrm{G} 2) ; \mathrm{R}=2$-ethyl-hexyl.

tion profiles of $\mathbf{G} 1$ and $\mathbf{G} 2$ are characterized by two main absorption bands, in analogy with other benzothiadiazole-based organic dyes. ${ }^{[14]}$

Concerning the lower energy band, the structural modification of the $\pi$-bridge did not lead to substantial differences in the absorption maxima of the two dyes, observed at 539 and $538 \mathrm{~nm}$ for $\mathbf{G} 1$ and G2, respectively. Consequently, their absorption onset in THF solution was very similar $(636 \mathrm{~nm})$. Furthermore, the broad absorption profile in the visible region was also accompanied by high molar extinction coefficients ( $\varepsilon=24000$ and $20000 \mathrm{M}^{-1} \mathrm{~cm}^{-1}$ for $\mathbf{G} 1$ and $\mathbf{G} 2$, respectively). The absorption peak in the UV region was characterized by a relatively higher intensity and appeared at $373 \mathrm{~nm}$ for both molecules $\left(\varepsilon=28500 \mathrm{M}^{-1} \mathrm{~cm}^{-1}\right.$ and $23200 \mathrm{M}^{-1} \mathrm{~cm}^{-1}$ for $\mathbf{G} 1$ and G2, respectively).

Considering that the absorption spectra of organic sensitizers on mesoporous $\mathrm{TiO}_{2}$ can be heavily affected by scattering effects and in order to predict the aggregation behavior of the $\pi$-extended dyes once absorbed onto the $\mathrm{TiO}_{2}$ surface, the optical properties of $\mathbf{G 1}$ and $\mathbf{G} 2$ were investigated in the solid state as thin films on quartz substrates. Significant differences can be observed in the optical behavior of the two dyes in the solid state: in fact, inspection of Figure S1B in the Supporting Information reveals a red-shift of the absorption maximum and a remarkable broadening of the absorption profile of the thiophene-based dye $\mathbf{G 1}\left(\lambda_{\max }=551 \mathrm{~nm}\right)$ with respect to its benzene-based counterpart $\mathbf{G 2}\left(\lambda_{\max }=541 \mathrm{~nm}\right)$. This result indicates that the nature of the $\pi$-bridge has a remarkable influence on the solid state properties of the materials and, in par- ticular, that the presence of the thiophene unit in $\mathbf{G} 1$ seems to bring about stronger intermolecular interactions, favoring accumulated $\pi-\pi$ interactions and leading to dye aggregation.

The solvatochromic behavior of an organic sensitizer is particularly useful in order to anticipate the modifications of the absorption profile consequent to the dye adsorption on $\mathrm{TiO}_{2}$. Since in the absorption process the free $-\mathrm{COOH}$ group is very likely converted into a titanium carboxylate ${ }^{[16]}$ a detrimental blue-shift of the dye absorption maximum can commonly be observed, caused by the lower electron acceptor character of the carboxylate moiety with respect to the carboxylic acid group. In order to rule out aggregation and scattering effects, it was chosen to record the UV/Vis spectra of the dyes in THF solution and in the presence of an excess of a base (triethylamine, TEA) or of an acid (formic acid), as shown in Figure S2. The use of a large excess $\left(\approx 10^{5} \mathrm{~mol}\right.$ per mol) of TEA was conceived to directly investigate in solution the optical behavior of the deprotonated form of the dye. We were pleased to find that the absorption profiles of $\mathbf{G 1}$ and $\mathbf{G} 2$ recorded either in the presence or in the absence of TEA were very similar and, practically superimposable in the visible region. It can be deduced that, in these $D-A-\pi-A$ structures, the presence of benzothiadiazole as additional electron-withdrawing group as well as of the further $\pi$-bridge extension, reduces the contribution of the carboxylic functionality to the electronic transitions, thereby preserving the light-harvesting properties of these molecules from the blue shift induced by the deprotonation. These results were substantiated by the optical responses of G1 and G2 in the presence of formic acid. Again, the absence 
of a significant modification in the absorption profiles rules out a dependence of the dyes absorption behavior on the protonated or deprotonated form of the carboxylic functionality.

Another photophysical issue to be investigated for a promising organic sensitizer is the dye optical stability under the operating conditions of the device. An appropriate photo-stability accelerated test was therefore carried out. The photochemical stability of $\mathbf{G 1}$ and $\mathbf{G} \mathbf{2}$ was, therefore, studied by submitting a film of the dye to a high intensity UV-irradiation in air for $20 \mathrm{~min}$. The high-energy photons contained in the UV radiation constitute a significant portion $(\approx 5 \%)$ of the solar spectrum and can be responsible for a degradation of the dye, inducing modifications on its absorption intensity and profile. ${ }^{[17]}$ Moreover, possible degradation mechanisms of the dye might involve radical pathways that can be promoted by singlet oxygen formation under UV-light irradiation. ${ }^{[18]}$ The photo-oxidation treatment (Figure S3) did not promote substantial changes of either the absorbance or the absorption profile of $\mathbf{G 1}$ and G2. Although some regions of the sensitizers, such as the electron-rich triarylamine group or the ethynylene moiety, can be considered reasonably susceptible to an easy oxidative degradation, the presence of the electron-withdrawing benzothiadiazole unit in the structure of the extended $\pi$-bridge seems to impart a remarkably high intrinsic photo-stability to the molecules.

In order to verify the feasibility of the electron injection from the excited states of an organic dye to the $\mathrm{TiO}_{2}$ conduction band and of the possibility of dye regeneration by means of the electrolyte redox couple, the estimation of the HOMO (highest occupied molecular orbital) and LUMO energy values is mandatory. To this end, cyclic voltammetry (CV) techniques are commonly employed. A scan of the anodic region (Figure S4 and S5) revealed that $\mathbf{G 1}$ and $\mathbf{G} 2$ exhibit three subsequent oxidation events. However, due to the relevant contribution of the electron-donating triarylamine group to the HOMO electronic distribution (see theoretical calculations), only the first oxidation event (Figure S6 and S7) is reversible for both dyes. The evaluation of the HOMO energy levels (see the Experimental Section) led to very similar values $(-5.04$ and $-5.03 \mathrm{eV}$ ) for $\mathbf{G 1}$ and $\mathbf{G 2}$. The obtained results suggest that, in DSSCs, an efficient regeneration of the oxidized dyes by the iodide/triiodide couple is thermodynamically feasible, thus reducing the possibility of geminated recombination. A similar behavior is observed for the cathodic process of $\mathbf{G 1}$ and G2, characterized by three reduction events, of which only the first is fully reversible (Figure S5 and S6). The obtained LUMO values of $\mathbf{G 1}$ and $\mathbf{G} 2$ are -3.16 and $-3.18 \mathrm{eV}$, respectively. The calculated LUMO energy values lie above the conduction band edge of $\mathrm{TiO}_{2}(-4.0 \mathrm{eV})$, ensuring sufficient driving force for electron injection from the excited dyes into the conduction band of the inorganic semiconductor. Furthermore, the obtained electrochemical band-gap of $\mathbf{G 1}$ and $\mathbf{G} 2$ (1.88 and $1.85 \mathrm{eV}$, respectively) is in good agreement with that obtained by optical measurements.

Together with the photo-stability, the electrochemical stability of an organic sensitizer is a critical factor in assessing the potential lifetime of a DSSC, since degradation of an organic dye might also occur in its oxidized state. In solid state CV experiments, the molecules of the first active layer are not replaced at the electrode interface and, therefore, repeated anodic scans mimic the oxidation and regeneration cycles occurring in the device. As evident from Figure S8, the CV anodic waves of $\mathbf{G} 1$ and $\mathbf{G} 2$ did not undergo substantial modifications after repeated scans, revealing their electrochemical stability under oxidative conditions in the time scale of the experiment. This result hints that no decomposition occurs while G1 and G2 are in their oxidized states. It is reasonable to suppose that, in these sensitizers, the sufficient stabilization of the dye oxidized form, as a result of hole delocalization, inhibits degradation pathways, which, conversely, are highly favored when holes are localized on specific carbon atoms. ${ }^{[19]}$ Considering that, during a single CV oxidation scan, the formed cations persist for approximately $2-3 \mathrm{~s}$ and that seven oxidation cycles were performed, $\mathbf{G} 1$ and $\mathbf{G} 2$ remained stable in their oxidized states for $\approx 15-20 \mathrm{~s}$. Applying Katoh's evaluation ${ }^{[6 a]}$ to the electrochemical stability, a dye lifetime of 15-20 year can be conjectured for $\mathbf{G} \mathbf{1}$ and $\mathbf{G} \mathbf{2}$.

\section{Theoretical calculations}

In order to provide a theoretical basis to the structure-property relationships emerging from the previously described investigations, as well as to properly discuss the behavior of the synthesized dyes in DSSC devices, we investigated appropriate models of $\mathbf{G 1}$ and $\mathbf{G} 2$ by density functional theory (DFT) and time-dependent DFT (TD-DFT) calculations. The calculations were carried out at the ground state on isolated molecules at the B3LYP/6-31G $(d, p)$ level of the theory. To reduce the computational load, the 2-ethyl-hexyl chains were replaced by methyl groups. The study of the optimized geometry of the molecules was addressed first. It was found that the torsion angles between the aryl planes present on the $\pi$-bridges ranged between $0.42^{\circ}$ and $1.91^{\circ}$, indicating their near-planarity, favored by the presence of the ethynylene spacers between the aryl moieties. ${ }^{[20]}$

The calculated electron density distributions of the main energetic levels along with the optimized geometry obtained for G1 and G2 are shown in Figure S9. Their HOMOs are very similar and mainly distributed on the electron-rich triarylamine group as well as on part of the $\pi$-bridge, suggesting that the electron binding energy for the HOMO is not sensitive to the structural difference between the two dyes, as observed for the measured redox energies. Conversely, the LUMOs of G1 and $\mathbf{G} 2$ are mainly described by the $\pi-A$ segment and, therefore, localized on the anchoring group, well separated from the HOMO electronic distribution. To overcome the approximation of the Koopmans' theorem, the ionization potential (minus HOMO) of $\mathbf{G} 1$ and $\mathbf{G} 2$ was calculated as the difference between the total energies of the $\mathrm{N}$-1-electron and $\mathrm{N}$-electron states, while their electron affinities (minus LUMO) as the difference between the total energies of the $\mathrm{N}$-electron and $\mathrm{N}+$ 1-electron states. ${ }^{[21]}$ All energies were calculated starting from the geometrically optimized structures of both dyes. The calculations returned the same results for the ionization potentials 
of $\mathbf{G} 1$ and $\mathbf{G} 2(-5.65 \mathrm{eV})$, while a slight difference was observed for their electron affinities $(-2.27$ and $-2.15 \mathrm{eV}$ for $\mathbf{G} 1$ and $\mathbf{G 2}$, respectively). Despite the discrepancy between theoretical and experimental values of ionization potential and electron affinities, attributable to the fact that calculations were carried out in vacuo, the trend observed for the calculated results strictly followed that experimentally obtained by electrochemistry. Furthermore, it is of interest to gain insights into the geometric localization of the hole of the oxidized dyes (described by the LUMO of the N-1electron state) since an accepting molecular orbital of the oxidized sensitizer placed in proximity of the anchoring group might promote geminate recombination during operation of the DSSC, consequently lowering the overall performances. ${ }^{[14 \mathrm{e}]}$ As evidenced in Figure S10, the hole of the oxidized $\mathbf{G 2}$ is mainly localized on the dithienyl-benzothiadiazole segment of the $\pi$-bridge and, due to the presence of the ethynylene-phenylene spacer, distinctly separated from the anchoring portion of the sensitizer. Conversely, due to the presence of a lower energy unit (thiophene vs benzene), the hole of the oxidized G1 seems to be delocalized along the entire $\pi$-bridge and extending up to the anchoring moiety. These results suggest more relevant geminate recombination effects for $\mathbf{G} 1$ with respect to G2 in DSSC devices. The stronger intermolecular interactions, indicated by the solid state optical properties of $\mathbf{G 1}$ are supported by its larger calculated dipole moment (12.5 Debye) with respect to that calculated for G2 (9.2 Debye).

A deeper understanding of the optical behavior of the two sensitizers was provided by the calculation of the vertical $\mathrm{S}_{0} \rightarrow \mathrm{S}_{n}$ excitation energies at the TDDFT level of theory using the CAM-B3LYP functional. Table 1 shows that the experimental and calculated optical data, in terms of both excitation energies and oscillator strength, are in good agreement. According to the calculation, for $\mathbf{G} 1$ and $\mathbf{G} 2$, the excitation in the visible region corresponds to a $S_{0} \rightarrow S_{1}$ transition, predominantly described as HOMO $\rightarrow$ LUMO, although with additional and significant HOMO- $1 \rightarrow$ LUMO and $\mathrm{HOMO} \rightarrow$ $\mathrm{LUMO}+1$ contributions. The $\mathrm{S}_{0} \rightarrow \mathrm{S}_{2}$ transition, corresponding to the absorption experimentally observed in the UV region, is mainly ascribed to a HOMO- $1 \rightarrow$ LUMO transition for both $\mathbf{G 1}$ and G2, although with other

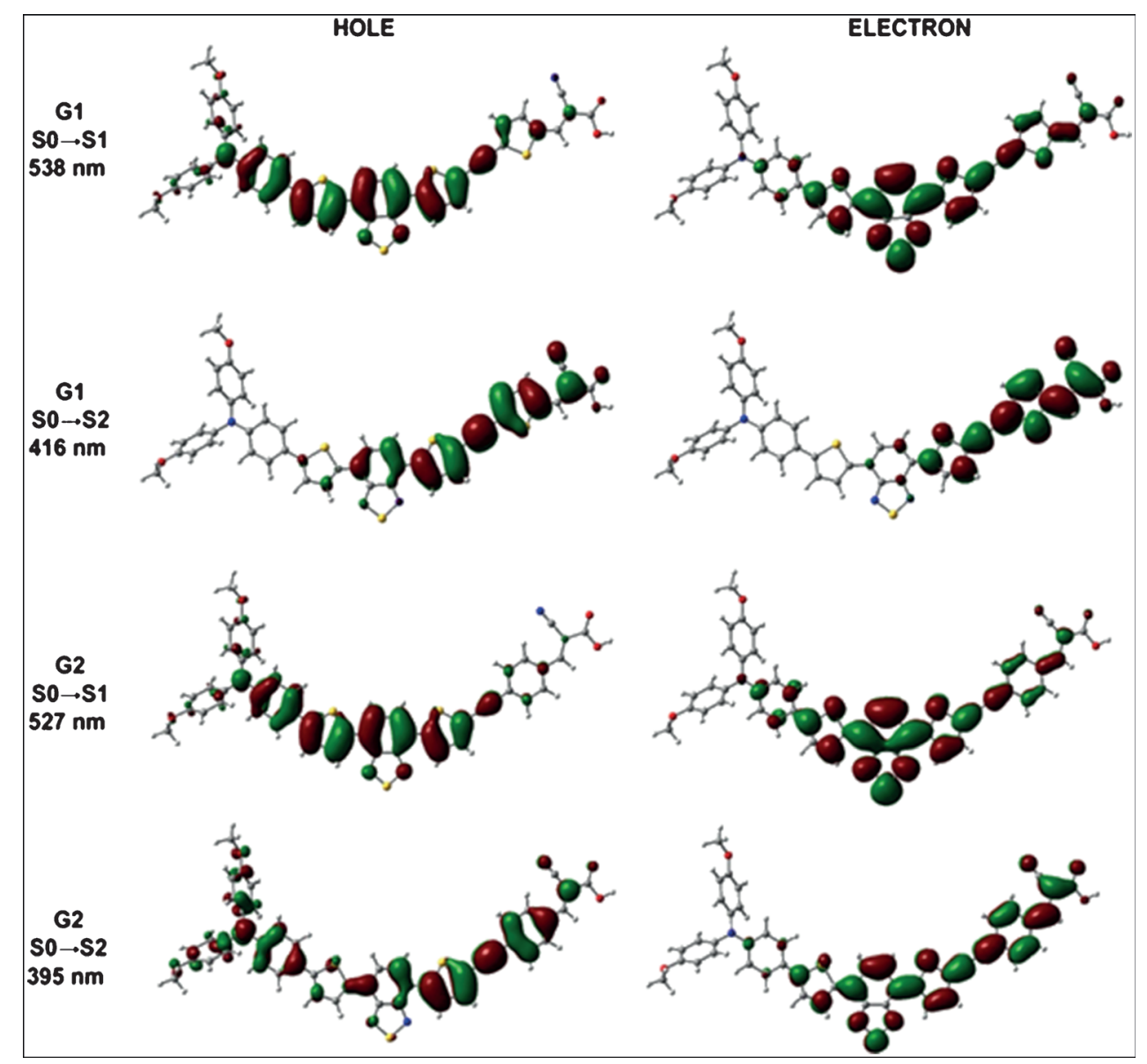

Figure 2. Calculated natural transition orbitals defining the photo-excitation dynamics in G1 and G2. 
tested in photo-electrochemical solar cells and their performances have also been investigated by electrochemical impedance spectroscopy (EIS).

Due to the high planarity of the sensitizers, resulting from the presence of the ethynyl-thiophene $(\mathrm{G} 1)$ and of the ethynylbenzene (G2) spacers, a fast intramolecular charge-transfer should be expected as well as an unfavorable $\pi-\pi$ stacking during the uptake process, which may lead to intermolecular quenching or back transfer of the injected electrons from the $\mathrm{TiO}_{2}$ conduction band. On this basis, the use of chenodeoxycholic acid (CDCA) as coadsorbent was evaluated. By competing with the dye for binding on the titania surface, the CDCA can, in fact, fill the gaps between the bulky sensitizers, thus minimizing detrimental dye aggregation effects. ${ }^{[14]}$ Moreover, the use of a co-adsorbent such as CDCA ensures a uniform coverage of the inorganic semiconductor, thereby lowering the probability of recombination between injected electrons with $\mathrm{I}_{3}{ }^{-}$and other acceptor species. ${ }^{[22]}$

Bearing this in mind, we focused on the fabrication of G1and G2-based DSSC by the implementation of the co-adsorption strategy. We started by preparing $0.2 \mathrm{~mm}$ solutions of $\mathbf{G 1}$ in THF with CDCA concentrations spanning the range 0 $100 \mathrm{~mm}$ and systematically studied the influence of the amount of additive on the photovoltaic parameters, as shown in Table 2. Despite the decrease in dye loading with the increase in CDCA concentration (Table 2), the performances (Figure S11) of the G1-sensitized device were improved. In particular, the open-circuit voltage $\left(V_{\text {oc }}\right)$ increased from 0.64 up to $0.69 \mathrm{~V}$ and the short-circuit photocurrent density $\left(U_{\mathrm{SC}}\right)$ raised from 7.4 up to $12.1 \mathrm{~mA} \mathrm{~cm}^{-2}$, with the best results at a CDCA concentration of $80 \mathrm{~mm}$. This amount of CDCA allows to achieve a power conversion efficiency (PCE) of $6.0 \%$, while that obtained for the G1-sensitized devices without the addition of CDCA did not exceed $3.5 \%$ due to the effect of dye aggregation. A further increase of the CDCA concentration (100 mM) led to a decrease of both $J_{\mathrm{SC}}$ and $V_{\mathrm{OC}}$, suggesting that, in these conditions, the additive unfavorably competes with the dye molecules for the anchoring sites.

After the screening carried out on G1, we decided to optimize the photovoltaic performances of $\mathbf{G} 2$ (Table 2) using CDCA at $80 \mathrm{~mm}$ concentration. The $J-V$ curves and the incident photon-to-current conversion efficiency (IPCE) spectra of DSSCs based on $\mathbf{G} 1$ and $\mathbf{G} 2$ dyes, in the presence and absence of CDCA, are shown in Figure 3 and Figure 4, respectively. Also in the case of the G2-based devices, the use of CDCA significantly enhanced the performances: the $J_{S C}$ was, in fact, increased from $10.4 \mathrm{mAcm}^{-2}$ to $15.9 \mathrm{~mA} \mathrm{~cm}^{-2}$. This result can be attributed to the higher electron injection efficiency in the devices obtained by G2/CDCA co-deposition. As expected, an in-

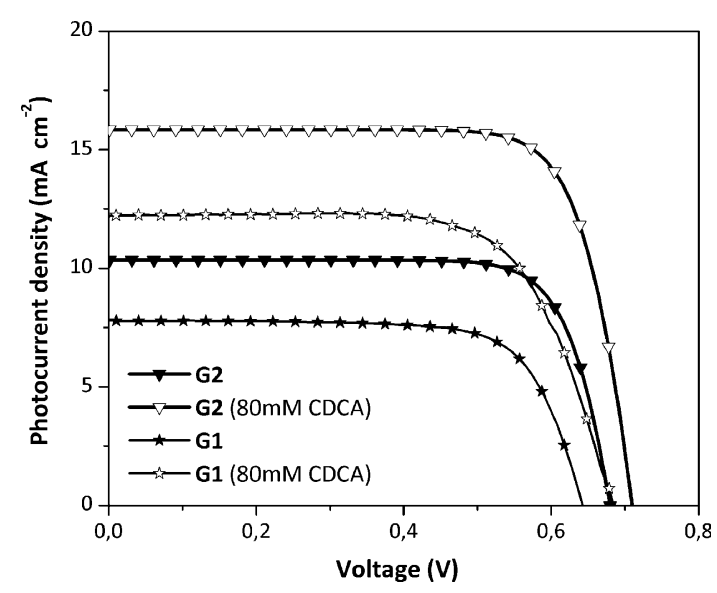

Figure 3. $J-V$ curves of the best devices based on $\mathbf{G 1}$ and $\mathbf{G} 2$ dyes used as reference without or with CDCA $(80 \mathrm{~mm})$ under 1 sun illumination.

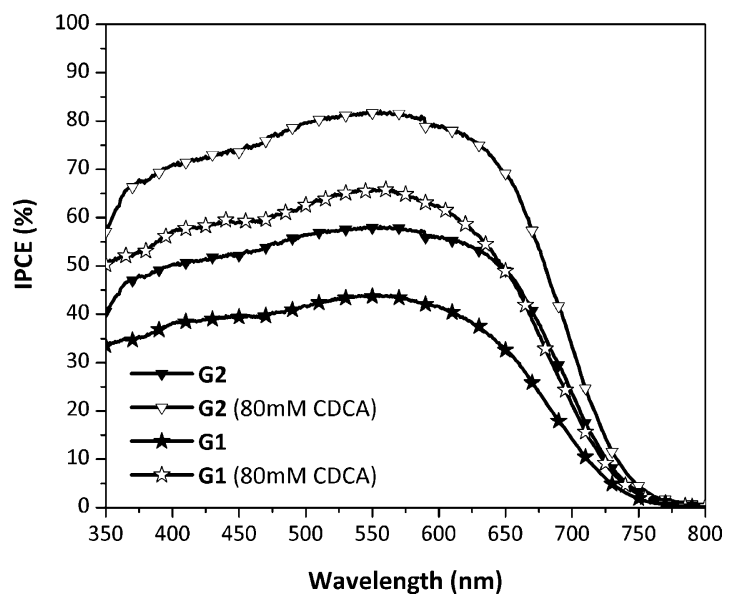

Figure 4. IPCE spectra of the best devices based on $\mathbf{G 1}$ and $\mathbf{G 2}$ dyes without or with CDCA (80 $\mathrm{mm})$.

Table 2. Photovoltaic parameters for DSSCs based on $\mathbf{G 1}$ and $\mathbf{G} 2$ dyes. $^{[\mathrm{a}]}$

\begin{tabular}{|lclllll} 
Dye & CDCA [mM] & PCE [\%] & $V_{\text {OC }}[\mathrm{V}]$ & $J_{\text {SC }}\left[\mathrm{mA} \mathrm{cm}^{-2}\right]$ & $F F^{[\mathrm{b}]}$ \\
\hline G1 & 0 & $3.5(3.3 \pm 0.2)$ & $0.64(0.65 \pm 0.01)$ & $7.4(7.1 \pm 0.3)$ & $0.72(0.70 \pm 0.02)$ & $3.0 \times 10^{-7}$ \\
& 10 & $4.1(3.9 \pm 0.2)$ & $0.66(0.67 \pm 0.01)$ & $8.4(8.1 \pm 0.5)$ & $0.73(0.72 \pm 0.01)$ & $2.4 \times 10^{-7}$ \\
& 60 & $5.2(5.0 \pm 0.2)$ & $0.69(0.69 \pm 0.01)$ & $10.4(10.0 \pm 0.4)$ & $0.72(0.72 \pm 0.02)$ & $1.8 \times 10^{-7}$ \\
& 80 & $6.0(5.6 \pm 0.4)$ & $0.69(0.69 \pm 0.01)$ & $12.2(11.9 \pm 0.4)$ & $0.71(0.69 \pm 0.02)$ & $1.2 \times 10^{-7}$ \\
G2 & 100 & $4.9(4.6 \pm 0.3)$ & $0.66(0.65 \pm 0.03)$ & $10.3(10.2 \pm 0.3)$ & $0.72(0.69 \pm 0.03)$ & $0.9 \times 10^{-7}$ \\
& 0 & $5.1(4.9 \pm 0.2)$ & $0.68(0.67 \pm 0.02)$ & $10.4(10.3 \pm 0.6)$ & $0.73(0.71 \pm 0.03)$ & $3.4 \times 10^{-7}$ \\
N719 & 80 & $8.1(7.9 \pm 0.2)$ & $0.71(0.71 \pm 0.01)$ & $15.9(15.3 \pm 0.6)$ & $0.72(0.72 \pm 0.01)$ & $1.3 \times 10^{-7}$ \\
& 0 & $8.2(8.1 \pm 0.2)$ & $0.75(0.75 \pm 0.01)$ & $14.8(14.8 \pm 0.7)$ & $0.74(0.73 \pm 0.04)$ & $2.1 \times 10^{-7}$ \\
& 80 & $2.7(2.6 \pm 0.1)$ & $0.76(0.77 \pm 0.01)$ & $4.2(4.2 \pm 0.3)$ & $0.83(0.80 \pm 0.03)$ \\
\hline
\end{tabular}

[a] Average values in parentheses are based on three replicate measurements. [b] Fill factor. 
crease in $V_{\mathrm{OC}}$ (from $0.68 \mathrm{~V}$ to $0.71 \mathrm{~V}$ ) was also observed for the G2/CDCA based devices, due to the attenuation of the recombination processes with the electrolyte. As a consequence, the PCE remarkably increased from $5.1 \%$ to $8.1 \%$, an efficiency value almost equal $(99 \%)$ to that obtained for the reference devices based on commercial N719 (8.2\%), giving the highest performance in the absence of the co-adsorbent. Remarkably, the efficiency of $\mathbf{G 1}$ was slightly higher than those reported for HKK-BTZ4, clearly pointing out the effect of the $\pi$-bridge extension.

The molecular structures of $\mathbf{G 1}$ and $\mathbf{G} 2$ differ only by the ethynylene-thiophene or ethynylene-benzene spacer, respectively, placed between the dithienyl-benzothiadiazole unit and the anchoring group. Nevertheless, the small structural modification on the $\pi$-bridge has a considerable effect on the DSSC performances. In fact, despite the slightly higher molar extinction coefficient of G1, which should lead to a better light harvesting capability, the G2-based devices showed slightly better performances. The superior $J_{S C}$ value for $\mathbf{G} 2$ also emerged from the IPCE spectra (Figure 4), which showed a plateau of approximately $80 \%$ at $550 \mathrm{~nm}$ for the G2/CDCA-based device compared to the plateau of approximately $60 \%$ obtained for the G1/CDCA-based one at $550 \mathrm{~nm}$. Given that, taking the absorption and reflection of the conductive glass into account, ${ }^{[14 f]}$ the IPCE should not exceed the limit of $\approx 80-90 \%$, it can be concluded that $\mathbf{G} 2$ presents nearly unity IPCE values in the visible region.

To further investigate this aspect and the relationship between co-adsorption of CDCA and photovoltaic performance, the charge-transfer resistance and the capacitance at the $\mathrm{TiO}_{2} /$ dye/electrolyte interface were measured by EIS. ${ }^{[23]}$ Since all devices were fabricated and tested in the same conditions, only the differences in the molecular structure of the sensitizers influenced the electrochemical parameters. EIS spectra were analyzed through the well-known equivalent circuit. ${ }^{[24]}$ All electrochemical parameters have been plotted as a function of the corrected potential; the measured potential needs, in fact, to be corrected in order to take into account the losses due to the total series resistance, which lead to a potential drop that is not associated with the displacement of the Fermi level. ${ }^{[25]}$

Figure S12 and Figure S13 show the measured capacitance $\left(C_{\text {meas }}\right)$ and the charge-transfer resistance $\left(R_{\mathrm{CT}}\right)$ as a function of corrected voltage for a set of devices based on $\mathbf{G 1}$ and $\mathbf{G} 2$ absorbed on $\mathrm{TiO}_{2}$ in the absence or in the presence of CDCA ( $80 \mathrm{~mm}$ ). From the analysis of $C_{\text {meas }}$ (Figure S12), it can be noticed that the G2/CDCA-based devices show the most relevant downward shift of the $\mathrm{TiO}_{2}$ conduction band edge. As it is well-known, the lower value of the conduction band facilitates the electron injection from the dye to the $\mathrm{TiO}_{2}$ resulting in higher photocurrents. Moreover, this downward shift decreases the energy difference with the potential of the redox mediator, leading to a decrease in $V_{\mathrm{OC}}$.

The lowest $R_{\mathrm{CT}}$ was found for the G1-based devices without CDCA, which confirms that injected electrons are more likely, under these conditions, to undergo recombination with the oxidized form of the redox species present in the electrolyte. The addition of CDCA to the $\mathbf{G 1}$ dye solution was helpful to in- crease the interfacial resistance of the obtained device, as indicated by the higher $V_{\text {OC }}$ measured (Table 2), mainly due to the blocking of recombination sites. On the other hand, a counterintuitive trend of the $R_{\mathrm{CT}}$ was evidenced for the G2-based photoanodes: the G2/CDCA devices showed lower $R_{\mathrm{CT}}$ values with respect to those in which no co-adsorbent was used. This result can be interpreted by comparing the recombination resistances at a similar number of injected electrons (i.e., at the same energy difference between the electron Fermi level and the $\mathrm{TiO}_{2}$ conduction band). ${ }^{[26]}$ The potential scales of Figure $\mathrm{S} 12$ and S13 have therefore been corrected in order to take into account the shift of the conduction band due to the electron injection. In Figure S14 and S15, the reported potential scale is the equivalent conduction band voltage $\left(V_{\text {ecb }}\right)$; the reference dye is $\mathbf{G 2}$ without CDCA. Inspection of Figure S15 confirms that CDCA-based devices show the highest $R_{\mathrm{CT}}$ values, indicating a better suppression of charge recombination effects and explaining the higher $V_{O C}$ observed for CDCA-based devices despite the lower value of the conduction band edge.

The electron lifetime $\left(\tau_{n}\right)$ in a DSSC is a fundamental parameter to assess the recombination dynamics and is defined as the average lifetime of free and trapped electrons in the $\mathrm{TiO}_{2}$ before recombination with the dye oxidized form or with the oxidant in the electrolyte. It is calculated by the following equation: $\tau_{\mathrm{n}}=R_{\mathrm{CT}} C_{\mu}$. The trend of the apparent electron lifetime, shown in Figure 5 , is in agreement with that revealed by the photovoltaic performance.

The higher electron lifetime observed for the G1/CDCA- and G2/CDCA-based DSSC confirms that the use of the coadsorbent leads to a suppression of the dark current. Comparing G1and G2-based devices under the same test condition, G2 shows longer electron lifetimes with respect to $\mathbf{G 1}$, implying that the recombination phenomena (geminate recombination and dark current) are considerably suppressed as also substantiated by the higher $V_{\text {OC }}$ values. From these results, it can be deduced that the electron transfer towards the $\mathrm{TiO}_{2}$ is more favored for $\mathbf{G} 2$ in comparison to $\mathbf{G 1}$. As suggested by the dye loading measurements, which indicate that the amount of the dye adsorbed onto the $\mathrm{TiO}_{2}$ surface for $\mathbf{G 1}$ and $\mathbf{G} 2$ is very simi-

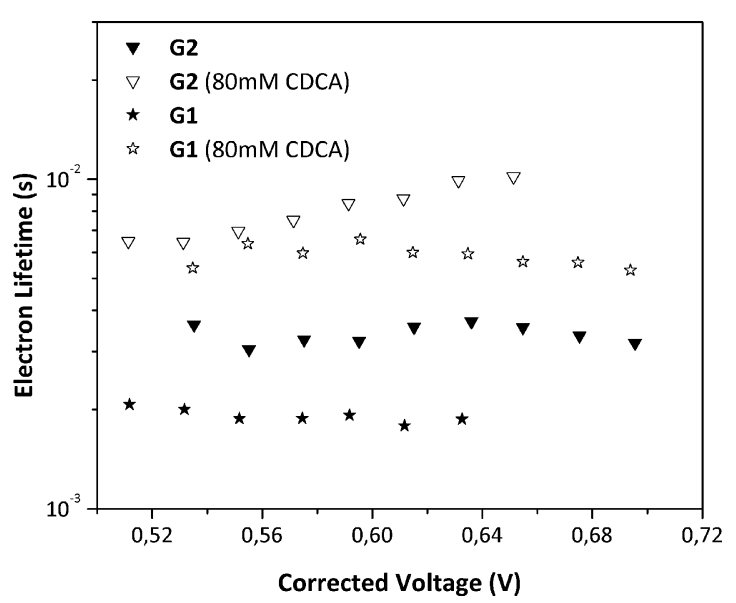

Figure 5. Apparent electron lifetime as a function of the corrected potential for DSSCs based on $\mathbf{G 1}$ and $\mathbf{G 2}$ dyes without or with CDCA ( $80 \mathrm{~mm}$ ). 
lar, it is reasonable to suppose that the CDCA presence has a lower disaggregating effect on $\mathbf{G 1}$ than on $\mathbf{G} 2$. In fact, it is the higher tendency of $\mathbf{G} 1$ towards aggregation due to the presence of the thiophene moiety (evidenced by the photophysical measurements) which can promote aradiative deactivation pathways for the excited states, lowering the probability of the electron injection.

On the other hand, the enhanced and unwanted electron recombination observed for the $\mathbf{G 1}$-based devices might be clarified by taking into account the potential interactions at the dye/electrolyte interface between iodine and an electron-rich heteroatom, ${ }^{[27]}$ which lead to the formation of iodine-dye adducts through the following displacement reaction:

dye $+\mathrm{I}_{3}^{-} \rightarrow$ dye- $\mathrm{I}_{2}+\mathrm{I}^{-}$.

In the case of $\mathbf{G 1}$, the presence of the thiophene unit in proximity to the mesoporous semiconductor might favor the onset of a dark current by electron transfer from the titania to the coordinated iodine.

\section{Conclusions}

Aiming at evaluating the effect of the $\pi$-bridge extension on their DSSC performances, two new low band-gap sensitizers were designed with $D-A-\pi-A$ structure containing: i) a triarylamine electron-donating group as the donor part, ii) a dithienylbenzothiadiazole chromophore, iii) a further ethynylene-thiophene (G1) or ethynylene-benzene (G2) $\pi$-spacer and iv) a cyano-acrylic moiety as acceptor and anchoring part. Regarding the classical weak points of the organic sensitizers (i.e., light-harvesting, stability), the new configuration brings several advantages: i) a broad absorption profile spanning the range $350-700 \mathrm{~nm}$; ii) the absence of hypsochromic shifts (the origin of which was substantiated by density functional theory) as a consequence of deprotonation, ascribable to the uncommon length of the $\pi$-bridge and the simultaneous presence of the electron-withdrawing benzothiadiazole unit; iii) an appreciable optical stability, ascertained by accelerated photo-degradation test, indicating the preservation of the light-harvesting properties of the synthesized organic dyes in DSSC devices; iv) a considerable electrochemical stability as thin films in the voltammetric oxidation/re-reduction cycles that suggest a remarkable dye stability also in their oxidized form. The interpretation on the optical and electrochemical properties of $\mathbf{G} 1$ and $\mathbf{G} 2$ were supported by DFT calculations. Indeed, the $\pi$-bridge structural modification on $\mathbf{G} 1$ and $\mathbf{G} 2$ seems to have a significant influence on dye aggregation and charge recombination, as pointed out by electrochemical impedance spectroscopy. In DSSC devices, the higher electron injection efficiency and injected electron lifetimes observed for $\mathbf{G} 2$ led to a superior power conversion efficiency, reaching $8.1 \%$ obtained with a suitable amount of a co-adsorbent (CDCA). Its performances are remarkably higher than those exhibited by $\mathbf{G 1}(6.0 \%)$ and slightly higher than those of literature congeners. Despite the serious problems of dye aggregation, overcome by the use of high amounts of CDCA $(80 \mathrm{~mm})$, these results indicate that $\pi$ - bridge extension is a viable strategy to improve dye efficiency and suggest analogous structural engineering of known low band-gap dyes as a promising strategy to obtain even more efficient organic sensitizers.

\section{Experimental Section}

General remarks: All reactants were purchased from standard commercial sources and used without any further purification. All solvents used were carefully dried and freshly distilled according to standard laboratory practice. All manipulations were carried out under inert nitrogen atmosphere. The synthesis of 4-(4,4,5,5-tetramethyl-1,3,2-dioxaborolan-2-yl)-N,N-bis(4-(2-ethyl-hexyloxy)phenyl)aniline and 4,7-bis-thiophen-2-yl-benzo[2,1,3]thiadiazole were carried out according to a literature procedure. ${ }^{[149]}$ Flash chromatography was performed using a silica gel of $230-400$ mesh. ${ }^{1} \mathrm{H}$ and $\left.{ }^{13} \mathrm{C}^{1} \mathrm{H}\right\}$ NMR spectra were recorded on a Bruker Avance $700 \mathrm{MHz}$ instrument. Melting points were measured on a Büchi B-545 instrument. Elemental analyses were obtained on a EuroVector CHNS EA3000 elemental analyser on the basis of three replicates. FTIR measurements were carried out on a JASCO FTIR 4200 spectrophotometer. UV/Vis spectra were recorded on a Jasco V-670 instrument. UV-photodecomposition experiments were carried out by irradiating the sample with a $150 \mathrm{~W}$ high-pressure $\mathrm{Hg}$ lamp for $20 \mathrm{~min}$. High resolution electrospray ionization mass spectrometry (HR ESI-MS) analyses were performed using a Bruker microTOF QII instrument equipped with an electrospray ion source. The sample solutions $\left(\mathrm{CH}_{2} \mathrm{Cl}_{2} / \mathrm{MeOH}\right)$ were introduced by continuous infusion at a flow rate of $180 \mu \mathrm{Lmin}^{-1}$ with the aid of a syringe pump. The instrument was operated in positive (negative) ion mode with endplate offset and capillary voltages set to $-500 \mathrm{~V}(500 \mathrm{~V})$ and $-4500 \mathrm{~V}(3500 \mathrm{~V})$, respectively. The nebulizer $\left(\mathrm{N}_{2}\right)$ pressure was $0.8 \mathrm{bar}$, and the drying gas $\left(\mathrm{N}_{2}\right)$ flow rate was $7.0 \mathrm{~L} \mathrm{~min}^{-1}$. The capillary exit and skimmer voltages were $90 \mathrm{~V}$ and $30 \mathrm{~V}$, respectively. The drying gas temperature was $180^{\circ} \mathrm{C}$. The calibration was carried out with sodium formate. Cyclic voltammetry was carried out on a Metrohm Autolab PGSTAT 302-N potentiostat. The materials were drop cast on a platinum working electrode from a $1 \mathrm{mg} \mathrm{mL}^{-1} \mathrm{THF}$ solution. Measurements were carried at $25^{\circ} \mathrm{C}$ in acetonitrile solution containing tetrabutylammonium tetrafluoroborate $(0.025 \mathrm{M})$ as supporting electrolyte with a scan rate of $50 \mathrm{mV} \mathrm{s}^{-1}$. The potentials were measured versus $\mathrm{Ag} / \mathrm{Ag}^{+}$as the quasi-reference electrode. After each experiment, the potential of the $\mathrm{Ag} / \mathrm{Ag}^{+}$electrode was calibrated against the ferrocene/ferrocenium $\left(\mathrm{Fc} / \mathrm{Fc}^{+}\right)$redox couple. The electrochemical energy gap was determined as the difference between the onsets of the oxidation and the reduction potentials $\left(E_{\mathrm{g}}{ }^{\mathrm{elc}}=E_{\mathrm{ox}}{ }^{\text {onset }}-E_{\text {red }}{ }^{\text {onset }}\right)$. The HOMO and LUMO energy values were estimated from the onset potentials of the first oxidation and reduction event, respectively. After calibration against Fc/ $\mathrm{Fc}^{+}$, the HOMO and LUMO energy levels were calculated according to the following equations: ${ }^{[28]}$

$E_{\text {номо }}(\mathrm{eV})=-\left[E_{\text {ох }}{ }^{\text {onset }}-E_{1 / 2}\left(\mathrm{Fc} / \mathrm{Fc}^{+}\right)+4.8\right]$

$E_{\text {Lumo }}(\mathrm{eV})=-\left[E_{\text {red }}{ }^{\text {onset }}-E_{1 / 2}\left(\mathrm{Fc} / \mathrm{Fc}^{+}\right)+4.8\right]$

where $E_{1 / 2}\left(\mathrm{Fc} / \mathrm{Fc}^{+}\right)$is the half-wave potential of the $\mathrm{Fc} / \mathrm{Fc}^{+}$couple (the formal potential of which is assumed to be $4.8 \mathrm{eV}$ in the Fermi scale) against the $\mathrm{Ag} / \mathrm{Ag}^{+}$electrode. Analyses of the ground-state structures for the molecules were carried out by density functional theory (DFT) calculations. The B3LYP function was used in conjunction with the $6-31 \mathrm{G}(\mathrm{d}, \mathrm{p})$ basis set. Time-dependent DFT (TD-DFT) was applied for the assessment of the excited-state transition ener- 
gies. All calculations were carried out with the Gaussian 09 program package ${ }^{[29]}$ and performed on isolated molecules in vacuo.

Fabrication of DSSC and photovoltaic measurement: Fluorinedoped tin oxide (FTO, $15 \Omega \mathrm{sq}^{-1}$, provided by Solaronix S.A.) glass plates were first cleaned in a detergent solution using an ultrasonic bath for $15 \mathrm{~min}$, and then rinsed with water and ethanol. Doublelayer electrodes (overall thickness $19 \mu \mathrm{m}$ ) were prepared as follows: a layer of commercial colloidal titania paste (Dyesol 18NR-T) was deposited onto the FTO glass and gradually heated in an oven in air to obtain $\mathrm{a} \sim 14 \mu \mathrm{m}$ transparent nanocrystalline film; the temperature gradient was programmed as follows: $170^{\circ} \mathrm{C}(40 \mathrm{~min})$, $350^{\circ} \mathrm{C}(15 \mathrm{~min})$, and $430^{\circ} \mathrm{C}$ (30 min). This procedure was repeated for the scattering layer $(5 \mu \mathrm{m})$ constituted by Solaronix D/SP colloidal paste. The double-layer electrode was eventually sintered at $450^{\circ} \mathrm{C}$ for $30 \mathrm{~min}$. The thickness and the active area $\left(0.16 \mathrm{~cm}^{2}\right)$ of the sintered photoanodes was measured using a profilometer (Veeco Dektak 150 Surface Profiler). The dye loading was performed by keeping the electrodes for $14 \mathrm{~h}$ and under dark in $0.2 \mathrm{~mm}$ THF solutions of $\mathbf{G} 1$ and $\mathbf{G} 2$ containing, where needed, a known amount of chenodeoxycholic acid (CDCA). The reference photoanodes were prepared analogously by dyeing the electrodes with $0.2 \mathrm{~mm}$ solutions of bis(tetrabutylammonium)-cis-di(thiocyanato)- $N, N^{\prime}$-bis(4-carboxylato-4'-carboxylic acid-2,2'-bipyridine) ruthenium(II) (N719, purchased by Solaronix S.A.) in a mixture of acetonitrile and tert-butyl alcohol $(1: 1 \mathrm{v} / \mathrm{v})$. In order to evaluate the dye loading capability, the sensitized photoelectrodes were placed in a solution of tetrabutylammonium hydroxide in DMF $(0.05 \mathrm{M})$ for $14 \mathrm{~h}$, whereas the N719-sensitized photoelectrodes were immersed in a $\mathrm{NaOH}$ aqueous solution $(0.01 \mathrm{M})$. The complete desorption was testified by the substrate discoloration. The evaluation of the dye concentration in the solvent, obtained by UV/Vis measurements, allowed the calculation of the amount of the adsorbed sensitizer, expressed in terms of moles of dye anchored per projected unit area of the photoelectrode. The counter-electrodes were prepared by sputtering a $50 \mathrm{~nm}$ Pt layer on a hole-drilled cleaned FTO plate. In a typical device construction procedure, the photoanode and the counter-electrode were faced and assembled using a suitably cut $50 \mu \mathrm{m}$ thick Surlyn hot-melt gasket for sealing. The redox electrolyte $\left(0.1 \mathrm{M}\right.$ Lil, $0.02 \mathrm{M} \mathrm{I}_{2}, 0.6 \mathrm{M}$ 1-methyl-3-propylimidazolium iodide, and $0.5 \mathrm{M}$ tert-butylpyridine in dry acetonitrile) was vacuum-injected into the space between the electrodes through pre-drilled holes on the back of the counter electrode. The holes were eventually sealed using Surlyn hot melt film and a cover glass. Photocurrent-voltage measurements were performed using a Keithley unit (Model 2400 Source Meter). A Newport AM 1.5 Solar Simulator (Model 91160A equipped with a $1000 \mathrm{~W}$ xenon arc lamp) serving as a light source. The light intensity (or radiant power) was calibrated to $100 \mathrm{~mW} \mathrm{~cm}^{-2}$ using as reference a Si solar cell. A mask with an aperture area of $0.25 \mathrm{~cm}^{2}$ was applied to the devices before measurements. The IPCE was measured by the DC method using a computer-controlled xenon arc lamp (Newport, $140 \mathrm{~W}$, 67005) coupled with a monochromator (Newport Cornerstore 260 Oriel 74125). The light intensity was measured by a calibrated silicon UV-photodetector (Oriel 71675) and the short circuit currents of the DSSCs were measured by using a dual channel optical power/ energy meter, (Newport 2936-C). EIS was performed by an AUTOLAB PGSTAT 302N (Eco Chemie B.V.) in a frequency range between $100 \mathrm{kHz}$ and $10 \mathrm{mHz}$. The impedance measurements were carried out at different voltage biases under 1.0 sun illumination. The resulting impedance spectra were fitted by using ZView (Scribner Associates) software.

Synthesis of 4-(5-bromo-thiophen-2-yl)-7-(thiophen-2-yl)-benzo$[2,1,3]$ thiadiazole $(1)$ : A solution of $N$-bromo-succinimide $(0.89 \mathrm{~g}$, $5.00 \mathrm{mmol})$ in DMF $(30 \mathrm{~mL})$ was added dropwise to a solution of 4,7-bis-thiophen-2-yl-benzo[2,1,3]thiadiazole $(1.51 \mathrm{~g}, 5.00 \mathrm{mmol})$ in DMF $(45 \mathrm{~mL})$ kept at $0^{\circ} \mathrm{C}$. After the addition, the obtained reaction mixture was warmed to room temperature and allowed to react for further $2 \mathrm{~h}$ before quenching with water $(50 \mathrm{~mL})$. The compound was extracted with diethyl ether $(3 \times 50 \mathrm{~mL})$ and the combined organic phases were washed with brine and dried over $\mathrm{Na}_{2} \mathrm{SO}_{4}$. After solvent removal, the crude product was purified by column chromatography $\left(\mathrm{SiO}_{2}\right.$, petroleum ether $40-60^{\circ} \mathrm{C} / \mathrm{CH}_{2} \mathrm{Cl}_{2}=$ $4: 1 \mathrm{v} / \mathrm{v})$ followed by crystallization with ethanol to afford $1(0.65 \mathrm{~g}$, $35 \%)$ as a red solid (mp: $\left.117.5 \pm 0.5^{\circ} \mathrm{C}\right) .{ }^{1} \mathrm{H}$ NMR $\left(700 \mathrm{MHz}, \mathrm{CDCl}_{3}\right)$ : $\delta=8.11(\mathrm{dd}, J=3.7,1.1 \mathrm{~Hz}, 1 \mathrm{H}), 7.86-7.73(\mathrm{~m}, 3 \mathrm{H}), 7.46(\mathrm{dd}, J=5.0$, $1.0 \mathrm{~Hz}, 1 \mathrm{H}), 7.20(\mathrm{dd}, J=5.0,3.9 \mathrm{~Hz}, 1 \mathrm{H}), 7.14 \mathrm{ppm}(\mathrm{d}, J=3.9 \mathrm{~Hz}$, $1 \mathrm{H}) .{ }^{13} \mathrm{C}\left\{{ }^{1} \mathrm{H}\right\}$ NMR $\left(176 \mathrm{MHz}, \mathrm{CDCl}_{3}\right): \delta=152.6,152.2,140.8,139.3$, 130.8, 128.1, 127.6, 127.4, 126.9, 126.4, 125.8, 125.1, 125.0, 114.6 ppm. HRMS (ESI) $\mathrm{m} / \mathrm{z}$ : $[\mathrm{M}+\mathrm{Na}]^{+}$calcd for $\mathrm{C}_{14} \mathrm{H}_{7} \mathrm{BrN}_{2} \mathrm{~S}_{3} \mathrm{Na}$ : 402.8825; found: 402.8873. IR (KBr): $\tilde{v}_{\max }=3090,1481,1423,1215$, $879,833 \mathrm{~cm}^{-1}$. Elemental analysis calcd for $\mathrm{C}_{14} \mathrm{H}_{7} \mathrm{BrN}_{2} \mathrm{~S}_{3}: \mathrm{C} 44.33, \mathrm{H}$ 1.86, N 7.39; found: C 44.17, H 1.86, N 7.36.

Synthesis of 4-(5-iodo-thiophen-2-yl)-7-(5-bromo-thiophen-2-yl)benzo[2,1,3]thiadiazole (2): $N$-iodo-succinimide (NIS, $0.56 \mathrm{~g}$, $2.47 \mathrm{mmol}$ ) was added portionwise to a solution of $1(0.75 \mathrm{~g}$, $1.98 \mathrm{mmol})$ in $\mathrm{CH}_{2} \mathrm{Cl}_{2}(50 \mathrm{~mL})$ and $\mathrm{CH}_{3} \mathrm{COOH}(50 \mathrm{~mL})$ at room temperature. The resulting mixture was allowed to react overnight before the addition of water $(50 \mathrm{~mL})$. The organic phase was then separated and dried over $\mathrm{Na}_{2} \mathrm{SO}_{4}$. Product $2(0.62 \mathrm{~g}, 62 \%)$ was obtained by solvent removal as a dark red solid; $\mathrm{mp}: 215.3 \pm 0.5^{\circ} \mathrm{C}$. ${ }^{1} \mathrm{H}$ NMR $\left(700 \mathrm{MHz}, \mathrm{CDCl}_{3}\right): \delta=7.84-7.81(\mathrm{~m}, 3 \mathrm{H}), 7.74(\mathrm{~d}, J=4.0 \mathrm{~Hz}$, $1 \mathrm{H}), 7.37(\mathrm{~d}, J=4.0,1 \mathrm{H}), 7.18 \mathrm{ppm}(\mathrm{d}, J=4.0 \mathrm{~Hz}, 1 \mathrm{H}) .{ }^{13} \mathrm{C}\left\{{ }^{1} \mathrm{H}\right\} \mathrm{NMR}$ $\left(176 \mathrm{MHz}, \mathrm{CDCl}_{3}\right): \delta=152.3,152.2,145.1,140.6,137.8,130.8$, $128.49,128.47,127.4,125.5,125.31,125.27,125.1,114.8$ ppm. HRMS (ESI) $\mathrm{m} / \mathrm{z}$ : $[\mathrm{M}+\mathrm{Na}]^{+}$calcd for $\mathrm{C}_{14} \mathrm{H}_{6} \mathrm{BrIN}_{2} \mathrm{~S}_{3} \mathrm{Na}$, 528.7791; found: 528.7002. IR (KBr): $\tilde{v}_{\max }=3081,1480,1412,1214,1074,872$, $832,792,509 \mathrm{~cm}^{-1}$. Elemental analysis calcd for $\mathrm{C}_{14} \mathrm{H}_{6} \mathrm{BrIN}_{2} \mathrm{~S}_{3}$ : C 33.28, H 1.20, N 5.54; found: C 33.34, H 1.20, N 5.52 .

Synthesis of 4-(5-((7-(5-bromo-thiophen-2-yl)-benzo$[2,1,3]$ thiadiazol-4-yl)-thiophen-2-yl)- $N, N$-bis(4-(2-ethyl-hexyl-

oxy)phenyl)-aniline (3): A mixture of 4-(4,4,5,5-tetramethyl-1,3,2-dioxaborolan-2-yl)-N,N-bis(4-(2-ethyl-hexyloxy)phenyl)-aniline $(1.18 \mathrm{~g}$, $1.88 \mathrm{mmol}), 2(0.95 \mathrm{~g}, 1.88 \mathrm{mmol})$ and $\mathrm{Pd}\left(\mathrm{PPh}_{3}\right)_{4}(0.11 \mathrm{~g}, 9.4 \times$ $\left.10^{-2} \mathrm{mmol}\right)$ in THF $(24 \mathrm{~mL})$ and a $1 \mathrm{M} \mathrm{NaHCO}$ aqueous solution $(18 \mathrm{~mL})$ was refluxed for $24 \mathrm{~h}$. After cooling down the reaction to room temperature, methylene chloride $(50 \mathrm{~mL})$ was added to the mixture and the resulting organic phase was separated, washed with water $(50 \mathrm{~mL})$ and dried over $\mathrm{Na}_{2} \mathrm{SO}_{4}$. After solvent removal, the crude product was purified by column chromatography $\left(\mathrm{SiO}_{2}\right.$, petroleum ether $\left.\left(40-60^{\circ} \mathrm{C}\right) / \mathrm{CH}_{2} \mathrm{Cl}_{2}=7: 3 \mathrm{v} / \mathrm{v}\right)$ to obtain $3(1.23 \mathrm{~g}$, $74 \%)$ as a purple solid, $\mathrm{mp}: 63.6 \pm 0.5^{\circ} \mathrm{C} .{ }^{1} \mathrm{H}$ NMR $\left(700 \mathrm{MHz}, \mathrm{CDCl}_{3}\right)$ : $\delta=8.12(\mathrm{~d}, J=3.9 \mathrm{~Hz}, 1 \mathrm{H}), 7.86-7.77(\mathrm{~m}, 4 \mathrm{H}), 7.51(\mathrm{~d}, J=8.7 \mathrm{~Hz}$, $2 \mathrm{H}), 7.16(\mathrm{~d}, J=4.0 \mathrm{~Hz}, 1 \mathrm{H}), 7.10(\mathrm{~d}, J=8.7 \mathrm{~Hz}, 4 \mathrm{H}), 6.96(\mathrm{~d}, J=$ $8.5 \mathrm{~Hz}, 2 \mathrm{H}), 6.87(\mathrm{~d}, J=8.7 \mathrm{~Hz}, 4 \mathrm{H}), 3.91-3.81(\mathrm{~m}, 4 \mathrm{H}), 1.79-1.71$ $(\mathrm{m}, 2 \mathrm{H}), 1.57-1.39(\mathrm{~m}, 8 \mathrm{H}), 1.38-1.32(\mathrm{~m}, 8 \mathrm{H}), 1.00-0.91 \mathrm{ppm}(\mathrm{m}$, $12 \mathrm{H}) .{ }^{13} \mathrm{C}\left\{{ }^{1} \mathrm{H}\right\}$ NMR $\left(176 \mathrm{MHz}, \mathrm{CDCl}_{3}\right): \delta=156.1,152.44,152.40$, $146.4,140.9,140.2,137.8,137.0,130.74,130.66,129.1,127.4,126.9$, 126.8, 126.5, 125.3, 124.8, 124.4, 122.7, 120.1, 115.4, 114.3, 70.8, 39.5, 30.6, 29.1, 23.9, 23.1, 14.1, $11.2 \mathrm{ppm}$. HRMS (ESI) $\mathrm{m} / \mathrm{z}$ : $[\mathrm{M}]^{+}$ calcd for $\mathrm{C}_{48} \mathrm{H}_{52} \mathrm{BrN}_{3} \mathrm{O}_{2} \mathrm{~S}_{3}, 879.2387$; found: 879.2433. IR (KBr): $\tilde{v}_{\max }=$ $3038,2950,1600,1318,1106,1033,827,722,511 \mathrm{~cm}^{-1}$. Elemental analysis calcd for $\mathrm{C}_{48} \mathrm{H}_{52} \mathrm{BrN}_{3} \mathrm{O}_{2} \mathrm{~S}_{3}$ : C 65.58, H 5.96, N 4.78; found: $\mathrm{C}$ $65.51, \mathrm{H} 5.98, \mathrm{~N} 4.76$.

Synthesis of 4-(5-((7-(5-trimethylsilylethynyl-thiophen-2-yl)benzo[2,1,3]thiadiazol-4-yl)-thiophen-2-yl)- $N, N$-bis(4-(2-ethylhexyloxy)phenyl)-aniline (4): A mixture of $3(0.70 \mathrm{~g}, 0.80 \mathrm{mmol})$, $\mathrm{PdCl}_{2}\left(\mathrm{PPh}_{3}\right)_{2} \quad\left(28.1 \mathrm{mg}, \quad 4.0 \times 10^{-2} \mathrm{mmol}\right), \quad \mathrm{Cul} \quad(3.8 \mathrm{mg}, \quad 2.0 \times$ $\left.10^{-2} \mathrm{mmol}\right)$, trimethylsilyl-acetylene $(0.10 \mathrm{~g}, 1.03 \mathrm{mmol})$ in diethyla- 
mine $(10 \mathrm{~mL})$ was refluxed overnight. After cooling down the reaction to room temperature, methylene chloride $(50 \mathrm{~mL})$ was added to the mixture and the resulting organic phase was washed with water $(50 \mathrm{~mL})$ and dried over $\mathrm{Na}_{2} \mathrm{SO}_{4}$. After solvent removal, the crude product was purified by column chromatography $\left(\mathrm{SiO}_{2}\right.$, petroleum ether $\left.\left(40-60^{\circ} \mathrm{C}\right) / \mathrm{CH}_{2} \mathrm{Cl}_{2}=7 / 3 \mathrm{v} / \mathrm{v}\right)$ to obtain $4(0.39 \mathrm{~g}, 55 \%)$ as a purple solid; mp: $69.3 \pm 0.5^{\circ} \mathrm{C}$. ${ }^{1} \mathrm{H}$ NMR $\left(700 \mathrm{MHz}, \mathrm{CDCl}_{3}\right): \delta=$ $8.14(\mathrm{~d}, J=3.9 \mathrm{~Hz}, 1 \mathrm{H}), 7.96(\mathrm{~d}, J=3.9 \mathrm{~Hz}, 1 \mathrm{H}), 7.88-7.85(\mathrm{~m}, 2 \mathrm{H})$, $7.51(\mathrm{~d}, J=8.7 \mathrm{~Hz}, 2 \mathrm{H}), 7.34-7.29(\mathrm{~m}, 2 \mathrm{H}), 7.10(\mathrm{~d}, J=8.7 \mathrm{~Hz}, 4 \mathrm{H})$, $6.96(\mathrm{~d}, J=8.5 \mathrm{~Hz}, 2 \mathrm{H}), 6.87(\mathrm{~d}, J=8.7 \mathrm{~Hz}, 4 \mathrm{H}), 3.89-3.82(\mathrm{~m}, 4 \mathrm{H})$, 1.76-1.72 (m, 2H), 1.57-1.39 (m, 8H), 1.38-1.33 (m, 8H), 0.98-0.92 $(\mathrm{m}, 12 \mathrm{H}), 0.30 \mathrm{ppm}(\mathrm{s}, 9 \mathrm{H}) .{ }^{13} \mathrm{C}\left\{{ }^{1} \mathrm{H}\right\}$ NMR $\left(176 \mathrm{MHz}, \mathrm{CDCl}_{3}\right): \delta=$ $156.0,152.6,152.5,148.8,146.5,140.8,140.2,137.0,133.4,129.2$, $126.8,126.72,126.69,126.5,125.9,125.8,124.8,124.6,124.3,122.7$, 120.1, 115.4, 100.8, 97.7, 70.8, 39.5, 30.6, 29.7, 29.1, 23.9, 23.1, 14.1, $11.2,-0.1 \mathrm{ppm}$. HRMS (ESI) $\mathrm{m} / \mathrm{z}:[\mathrm{M}]^{+}$calcd for $\mathrm{C}_{53} \mathrm{H}_{61} \mathrm{~N}_{3} \mathrm{O}_{2} \mathrm{~S}_{3} \mathrm{Si}$, 895.3690; found: 895.3730. IR (KBr): $\tilde{v}_{\max }=2956,2857,2149,1600$, $1504,1484,1447,1238,1035,855,798 \mathrm{~cm}^{-1}$. Elemental analysis calcd for $\mathrm{C}_{53} \mathrm{H}_{61} \mathrm{~N}_{3} \mathrm{O}_{2} \mathrm{~S}_{3} \mathrm{Si}$ : C 71.02, $\mathrm{H} 6.86, \mathrm{~N} 6.69$; found: $\mathrm{C} 71.10, \mathrm{H}$ $6.84, \mathrm{~N} 6.70$.

\section{Synthesis of 4-(5-((7-(5-ethynyl-thiophen-2-yl)-benzo-} $[2,1,3]$ thiadiazol-4-yl)-thiophen-2-yl)- $\mathrm{N}, \mathrm{N}$-bis(4-(2-ethyl-hexyloxy)phenyl)-aniline (5): A mixture of $4(0.38 \mathrm{~g}, 0.42 \mathrm{mmol})$ and $\mathrm{KF}$ $(0.12 \mathrm{~g}, 2.10 \mathrm{mmol})$ in methylene chloride $(6 \mathrm{~mL})$ and methanol $(6 \mathrm{~mL})$ was stirred for $30 \mathrm{~min}$ at $55^{\circ} \mathrm{C}$. After cooling down the reaction mixture to room temperature, methylene chloride $(50 \mathrm{~mL})$ was added and the resulting organic phase washed with water $(50 \mathrm{~mL})$ and dried over $\mathrm{Na}_{2} \mathrm{SO}_{4}$. After solvent removal, the crude product was purified by column chromatography $\left(\mathrm{SiO}_{2}\right.$, petroleum ether $\left.\left(40-60{ }^{\circ} \mathrm{C}\right) / \mathrm{CH}_{2} \mathrm{Cl}_{2}=4 / 1 \mathrm{v} / \mathrm{v}\right)$ obtaining $5(0.36 \mathrm{~g}, 99 \%)$ as a purple solid; $\mathrm{mp}: 88.0 \pm 0.5^{\circ} \mathrm{C} .{ }^{1} \mathrm{H} \mathrm{NMR}\left(700 \mathrm{MHz}, \mathrm{CDCl}_{3}\right): \delta=8.14$ (d, $J=$ $3.9 \mathrm{~Hz}, 1 \mathrm{H}), 7.97(\mathrm{~d}, J=3.9 \mathrm{~Hz}, 1 \mathrm{H}), 7.87-7.85(\mathrm{~m}, 2 \mathrm{H}), 7.51(\mathrm{~d}, J=$ $8.7 \mathrm{~Hz}, 2 \mathrm{H}), 7.37(\mathrm{~d}, J=3.8 \mathrm{~Hz}, 1 \mathrm{H}), 7.30(\mathrm{~d}, J=3.8 \mathrm{~Hz}, 1 \mathrm{H}), 7.10(\mathrm{~d}$, $J=8.7 \mathrm{~Hz}, 4 \mathrm{H}), 6.96(\mathrm{~d}, J=8.5 \mathrm{~Hz}, 2 \mathrm{H}), 6.87(\mathrm{~d}, J=8.7 \mathrm{~Hz}, 4 \mathrm{H})$, 3.88-3.81 $(\mathrm{m}, 4 \mathrm{H}), 3.49(\mathrm{~s}, 1 \mathrm{H}), 1.78-1.71(\mathrm{~m}, 2 \mathrm{H}), 1.57-1.39(\mathrm{~m}$, $8 \mathrm{H}), \quad 1.38-1.31(\mathrm{~m}, 8 \mathrm{H}), \quad 0.98-0.90 \mathrm{ppm}(\mathrm{m}, 12 \mathrm{H}) .{ }^{13} \mathrm{C}\left\{{ }^{1} \mathrm{H}\right\} \quad \mathrm{NMR}$ $\left(176 \mathrm{MHz}, \mathrm{CDCl}_{3}\right): \delta=156.0,152.6,152.5,148.8,146.5,141.1,140.2$, $136.9,133.9,129.2,126.9,126.8,126.72,126.68,126.5,126.10$, $125.8,124.7,124.5,122.7,120.1,120.0,115.4,82.8,70.8,39.5,30.6$, 29.1, 23.9, 23.1, 14.1, $11.2 \mathrm{ppm}$. HRMS (ESI) $\mathrm{m} / \mathrm{z}$ : $[\mathrm{M}]^{+}$calcd for $\mathrm{C}_{50} \mathrm{H}_{53} \mathrm{~N}_{3} \mathrm{O}_{2} \mathrm{~S}_{3}$, 823.3294; found: 823.3298. IR (KBr): $\tilde{v}_{\max }=3036,2956$, $2924,2857,2137,2094,1599,1503,1238,826,799 \mathrm{~cm}^{-1}$. Elemental

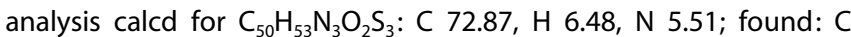
$72.80, \mathrm{H} 6.47, \mathrm{~N} 5.48$.

Synthesis of 5-((5-(7-(5-(4-(bis(4-(2-ethyl-hexyloxy)phenyl)amino)phenyl)thiophen-2-yl)benzo[2,1,3]thiadiazol-4-yl)-thiophen-2yl)ethynyl)thiophene-2-carbaldehyde (6): A mixture of $5(0.17 \mathrm{~g}$, $0.21 \mathrm{mmol})$ 5-bromo-thiophene-2-carbaldehyde (43.9 mg, $0.23 \mathrm{mmol}), \mathrm{Pd}\left(\mathrm{PPh}_{3}\right)_{4}\left(11.6 \mathrm{mg}, 1.0 \times 10^{-2} \mathrm{mmol}\right)$ and Cul $(1.9 \mathrm{mg}$, $\left.1.0 \times 10^{-2} \mathrm{mmol}\right)$ in diethylamine $(10 \mathrm{~mL})$ was refluxed for $24 \mathrm{~h}$. After cooling down the reaction mixture to room temperature, methylene chloride $(50 \mathrm{~mL})$ was added and the resulting organic phase was washed with water $(50 \mathrm{~mL})$ and dried over $\mathrm{Na}_{2} \mathrm{SO}_{4}$. After solvent removal, the crude product was purified by column chromatography $\left(\mathrm{SiO}_{2}, \mathrm{CH}_{2} \mathrm{Cl}_{2}\right)$ to yield $6(0.11 \mathrm{~g}, 59 \%)$ as a violet solid; $\mathrm{mp}: 95.0 \pm 0.5^{\circ} \mathrm{C} .{ }^{1} \mathrm{H} \mathrm{NMR}\left(700 \mathrm{MHz}, \mathrm{CDCl}_{3}\right): \delta=9.90(\mathrm{~s}, 1 \mathrm{H}), 8.16$ $(\mathrm{d}, J=3.9 \mathrm{~Hz}, 1 \mathrm{H}), 8.03(\mathrm{~d}, J=3.9 \mathrm{~Hz}, 1 \mathrm{H}), 7.91(\mathrm{~d}, J=7.6 \mathrm{~Hz}, 1 \mathrm{H})$, $7.88(\mathrm{~d}, J=7.6 \mathrm{~Hz}, 1 \mathrm{H}), 7.71(\mathrm{~d}, J=3.9 \mathrm{~Hz}, 1 \mathrm{H}), 7.53-7.50(\mathrm{~m}, 2 \mathrm{H})$, $7.45(\mathrm{~d}, J=3.9 \mathrm{~Hz}, 1 \mathrm{H}), 7.36(\mathrm{~d}, J=3.9 \mathrm{~Hz}, 1 \mathrm{H}), 7.31(\mathrm{~d}, J=3.9 \mathrm{~Hz}$, $1 \mathrm{H}), 7.12-7.09(\mathrm{~m}, 4 \mathrm{H}), 6.97-6.95(\mathrm{~m}, 2 \mathrm{H}), 6.89-6.86(\mathrm{~m}, 4 \mathrm{H}), 3.87-$ $3.83(\mathrm{~m}, 4 \mathrm{H}), 1.77-1.72(\mathrm{~m}, 2 \mathrm{H}), 1.57-1.39(\mathrm{~m}, 8 \mathrm{H}), 1.38-1.34(\mathrm{~m}$, $8 \mathrm{H}), 0.98-0.92 \mathrm{ppm}(\mathrm{m}, 12 \mathrm{H}) .{ }^{13} \mathrm{C}\left\{{ }^{1} \mathrm{H}\right\}$ NMR $\left(176 \mathrm{MHz}, \mathrm{CDCl}_{3}\right): \delta=$ $182.3,156.1,152.54,152.46,148.9,146.7,144.1,142.6,140.2,136.9$, 136.0, 134.0, 132.5, 132.4, 129.4, 127.1, 127.0, 126.9, 126.5, 126.2
125.7, 124.7, 124.2, 122.8, 122.6, 120.0, 115.4, 91.7, 87.5, 70.8, 39.5, $30.6,29.1,23.9,23.1,14.1,11.1 \mathrm{ppm}$. HRMS (ESI) $\mathrm{m} / \mathrm{z}:[\mathrm{M}]^{+}$calcd for $\mathrm{C}_{55} \mathrm{H}_{55} \mathrm{~N}_{3} \mathrm{O}_{3} \mathrm{~S}_{4}$, 933.3121; found: 933.3105. IR (KBr): $\tilde{v}_{\max }=3038,2954$, $2924,2868,2854,2180,1668,1504,1238,827,798 \mathrm{~cm}^{-1}$. Anal. calcd for $\mathrm{C}_{55} \mathrm{H}_{55} \mathrm{~N}_{3} \mathrm{O}_{3} \mathrm{~S}_{4}$ : C 70.70, H 5.93, N 4.50; found: C 70.65, H 5.91, N 4.51 .

Synthesis of 4-((5-(7-(5-(4-(bis(4-(2-ethyl-hexyloxy)phenyl)amino)phenyl)thiophen-2-yl)benzo[2,1,3]thiadiazol-4-yl)-thiophen-2yl)ethynyl)benzaldehyde (7): A mixture of $5(0.17 \mathrm{~g}, 0.21 \mathrm{mmol})$, 4-bromo-benzaldehyde $(41.9 \mathrm{mg}, 0.23 \mathrm{mmol}), \mathrm{Pd}\left(\mathrm{PPh}_{3}\right)_{4}(11.6 \mathrm{mg}$, $\left.1.0 \times 10^{-2} \mathrm{mmol}\right)$ and Cul $\left(1.9 \mathrm{mg}, 1.0 \times 10^{-2} \mathrm{mmol}\right)$ in diethylamine $(10 \mathrm{~mL})$ was refluxed for $24 \mathrm{~h}$. After cooling down the reaction mixture to room temperature, methylene chloride $(50 \mathrm{~mL})$ was added and the resulting organic phase was washed with water $(50 \mathrm{~mL})$ and dried over $\mathrm{Na}_{2} \mathrm{SO}_{4}$. After solvent removal, the crude product was purified by column chromatography $\left(\mathrm{SiO}_{2}, \mathrm{CH}_{2} \mathrm{Cl}_{2}\right)$ yielding 7 $(0.10 \mathrm{~g}, 53 \%)$ as a violet solid; $\mathrm{mp}: 97.6 \pm 0.5^{\circ} \mathrm{C} .{ }^{1} \mathrm{H}$ NMR $(700 \mathrm{MHz}$, $\left.\mathrm{CDCl}_{3}\right): \delta=10.05(\mathrm{~s}, 1 \mathrm{H}), 8.17(\mathrm{~d}, J=3.9 \mathrm{~Hz}, 1 \mathrm{H}), 8.04(\mathrm{~d}, J=3.9 \mathrm{~Hz}$, $1 \mathrm{H}), 7.94-7.88(\mathrm{~m}, 4 \mathrm{H}), 7.71(\mathrm{~d}, J=8.2 \mathrm{~Hz}, 2 \mathrm{H}), 7.52(\mathrm{~d}, J=8.8 \mathrm{~Hz}$, $2 \mathrm{H}), 7.45(\mathrm{~d}, J=3.8 \mathrm{~Hz}, 1 \mathrm{H}), 7.31(\mathrm{~d}, J=3.8 \mathrm{~Hz}, 1 \mathrm{H}), 7.11(\mathrm{~d}, J=$ $8.8 \mathrm{~Hz}, 4 \mathrm{H}), 6.97(\mathrm{~d}, J=8.8 \mathrm{~Hz}, 2 \mathrm{H}), 6.87(\mathrm{~d}, J=8.8 \mathrm{~Hz}, 4 \mathrm{H}), 3.88-$ $3.83(\mathrm{~m}, 4 \mathrm{H}), 1.77-1.71(\mathrm{~m}, 2 \mathrm{H}), 1.57-1.39(\mathrm{~m}, 8 \mathrm{H}), 1.38-1.34(\mathrm{~m}$, $8 \mathrm{H}), 0.98-0.92 \mathrm{ppm}(\mathrm{m}, 12 \mathrm{H}) .{ }^{13} \mathrm{C}\left\{{ }^{1} \mathrm{H}\right\}$ NMR $\left(176 \mathrm{MHz}, \mathrm{CDCl}_{3}\right): \delta=$ $191.3,156.1,152.6,152.5,148.9,146.6,142.0,140.2,136.9,135.5$, $133.7,131.8,129.6,129.3,129.2,127.02,126.97,126.9,126.5,126.1$, $125.7,124.7,124.4,123.4,122.7,120.0,115.4,94.1,87.2,70.8,39.5$, 30.6, 29.1, 23.9, 23.1, 14.1, $11.1 \mathrm{ppm}$. HRMS (ESI) $\mathrm{m} / \mathrm{z}$ : [M] ${ }^{+}$calcd for $\mathrm{C}_{57} \mathrm{H}_{57} \mathrm{~N}_{3} \mathrm{O}_{3} \mathrm{~S}_{3}, 927.3557$; found: 927.3620. IR (KBr): $\tilde{v}_{\max }=3036,2955$, $2924,2857,2193,1701,1482,1500,1235,827,798 \mathrm{~cm}^{-1}$. Elemental analysis calcd for $\mathrm{C}_{57} \mathrm{H}_{57} \mathrm{~N}_{3} \mathrm{O}_{3} \mathrm{~S}_{3}: \mathrm{N} 4.53, \mathrm{C} 73.75, \mathrm{H}$ 6.19; found: $\mathrm{N}$ 4.52, C 73.72, H 6.17.

Synthesis of 2-cyano-3-(5-((5--(7-(5-(4-(bis(4-(2-ethyl-hexyloxy)phenyl)amino)phenyl)-thiophen-2-yl)benzo[2,1,3]thiadiazol-4-yl)thiophen-2-yl)ethynyl)-thiophen-2-yl)acrylic acid (G1): A mixture of $6(0.10 \mathrm{~g}, 0.11 \mathrm{mmol})$, cyano-acetic acid $(45.9 \mathrm{mg}, 0.54 \mathrm{mmol})$ and ammonium acetate $\left(2.8 \mathrm{mg}, 3.6 \times 10^{-2} \mathrm{mmol}\right)$ in acetic acid $(10 \mathrm{~mL})$ was refluxed overnight. After cooling down the reaction to room temperature, the mixture was poured into water $(200 \mathrm{~mL})$ to obtain a precipitate that was collected by filtration and washed with water. The crude product was purified by column chromatography $\left(\mathrm{SiO}_{2}, \mathrm{CH}_{2} \mathrm{Cl}_{2} / \mathrm{MeOH}=10 / 1 \mathrm{v} / \mathrm{v}\right)$ to afford $\mathrm{G} 1$ (43.1 mg, 40\%) as a violet solid. ${ }^{2} \mathrm{H}$ NMR (700 MHz, $\left.\mathrm{CD}_{2} \mathrm{Cl}_{2} / \mathrm{CF}_{3} \mathrm{COOD}\right): \delta=8.58-8.40$ (br, 4H), 8.36-7.89 (br, 7H), 7.55-7.04 (br, 10H), 3.89-3.82 (br, 4H), $1.76-1.70(\mathrm{br}, 2 \mathrm{H}), 1.60-1.32(\mathrm{br}, 16 \mathrm{H}), 1.03-0.90 \mathrm{ppm}(\mathrm{br}, 12 \mathrm{H})$. HRMS (ESI) $\mathrm{m} / \mathrm{z}$ : $[M-\mathrm{H}]^{-}$calcd for $\mathrm{C}_{58} \mathrm{H}_{55} \mathrm{~N}_{4} \mathrm{O}_{4} \mathrm{~S}_{4}, 999.3101$; found: 999.3917. IR (KBr): $\tilde{v}_{\max }=3432,2960,2920,2876,2850,2214,2173$, $1617,1505,1378,1237,825,798 \mathrm{~cm}^{-1}$. Elemental analysis for $\mathrm{C}_{58} \mathrm{H}_{56} \mathrm{~N}_{4} \mathrm{O}_{4} \mathrm{~S}_{4}$ : C 69.57, H 5.64, N 5.60; found: C 69.45, H 5.66, N 5.59 .

Synthesis of 2-cyano-3-(4-((5--(7-(5-(4-(bis(4-(2-ethyl-hexyloxy)phenyl)amino)phenyl)-thiophen-2-yl)benzo[ $[2,1,3]$ thiadiazol-4-yl)thiophen-2-yl)ethynyl)-phenyl)acrylic acid (G2): A mixture of 7 $\left(86.4 \mathrm{mg}, 9.3 \times 10^{-2} \mathrm{mmol}\right)$, cyano-acetic acid $(39.6 \mathrm{mg}, 0.47 \mathrm{mmol})$ and ammonium acetate $\left(2.4 \mathrm{mg}, 3.1 \times 10^{-2} \mathrm{mmol}\right)$ in acetic acid $(10 \mathrm{~mL})$ was refluxed overnight. After cooling down the reaction to room temperature, the mixture was poured into water $(200 \mathrm{~mL})$ to obtain a precipitate that was collected by filtration and washed with water. The crude product was purified by column chromatography $\left(\mathrm{SiO}_{2}, \mathrm{CH}_{2} \mathrm{Cl}_{2} / \mathrm{MeOH}=10: 1 \mathrm{v} / \mathrm{v}\right)$ to give $\mathbf{G 2}(35.4 \mathrm{mg}, 38 \%)$ as a violet solid. ${ }^{1} \mathrm{H}$ NMR $\left(700 \mathrm{MHz}, \mathrm{CD}_{2} \mathrm{Cl}_{2} / \mathrm{CF}_{3} \mathrm{COOD}\right): \delta=8.59-8.41$ (br, 4H), 8.35-7.90 (br, 9H), 7.55-7.05 (br, 10H), 3.88-3.83 (br, 4H), 1.77-1.71 (br, 2H), $1.60-1.32(\mathrm{br}, 16 \mathrm{H}), 1.03-0.90 \mathrm{ppm}(\mathrm{br}, 12 \mathrm{H})$. HRMS (ESI) $\mathrm{m} / \mathrm{z}$ : $[\mathrm{M}-\mathrm{H}]^{-}$calcd for $\mathrm{C}_{60} \mathrm{H}_{57} \mathrm{~N}_{4} \mathrm{O}_{4} \mathrm{~S}_{3}, 993.3536$; found: 993.4329. IR (KBr): $\tilde{v}_{\max }=3432,2956,2925,2870,2855,2216,2193$, 
$1627,1505,1385,1235,827,798 \mathrm{~cm}^{-1}$. Elemental analysis calcd for $\mathrm{C}_{60} \mathrm{H}_{58} \mathrm{~N}_{4} \mathrm{O}_{4} \mathrm{~S}_{3}$ : C 72.40, H 5.87, N 5.63; found: C 72.33, H 5.88, N 5.61 .

\section{Acknowledgements}

Italian MIUR-PON project "Molecular Nanotechnologies for Health and Environment-MAAT" (PON02_005633316357-CUP B31C12001230005); the European Community Seventh Framework Programme (FP7/2007-2013) grant agreement $n^{\circ} 261920$ (Efficient Solar Cells based on Organic and hybrid TechnologyESCORT); Regione Puglia (APQ-Reti di Laboratorio, Project PHOEBUS, cod. 31-FE1.20001) and Daunia Wind are acknowledged for funding.

Keywords: benzothiadiazole $\cdot$ dye sensitized solar cell $\cdot$ lightharvesting - structure-property relationship $\cdot \pi$-extended organic sensitizer

[1] a) Y. Ooyama, Y. Harima, ChemPhysChem 2012, 13, 4032; b) A. Mishra, M. K. R. Fischer, P. Bäuerle, Angew. Chem. Int. Ed. 2009, 48, 2474; Angew. Chem. 2009, 121, 2510.

[2] a) S. Zhang, X. Yang, Y. Numata, L. Han, Energy Environ. Sci. 2013, 6 , 1443; b) A. Hagfeldt, G. Boschloo, L. Sun, L. Kloo, H. Pettersson, Chem. Rev. 2010, 110, 6595; c) L. Wang, X. Fang, Z. Zhang, Renewable Sustaina ble Energy Rev. 2010, 14, 3178.

[3] a) M. K. Nazeeruddin, E. Baranoff, M. Grätzel, Sol. Energy 2011, 85, 1172; b) N. Robertson, Angew. Chem. Int. Ed. 2006, 45, 2338; Angew. Chem. 2006, 118, 2398.

[4] a) A. Listorti, B. O'Regan, J. R. Durrant, Chem. Mater. 2011, 23, 3381; b) Z. Ning, H. Tian, Chem. Commun. 2009, 5483; c) S. Kim, J. K. Lee, S. O. Kang, J. Ko, J. H. Yum, S. Fantacci, F. De Angelis, D. Di Censo, M. K. Nazeeruddin, M. Grätzel, J. Am. Chem. Soc. 2006, 128, 16701.

[5] T. Marinado, K. Nonomura, J. Nissfolk, M. K. Karlsson, D. P. Hagberg, L. Sun, S. Mori, A. Hagfeldt, Langmuir 2010, 26, 15476

[6] a) R. Katoh, A. Furube, S. Mori, M. Miyashita, K. Sunahara, N. Koumura, K. Hara, Energy Environ. Sci. 2009, 2, 542; b) K. Hara, Z.-S. Wang, T. Sato A. Furube, R. Katoh, H. Sugihara, Y. Dan-oh, C. Kasada, A. Shimpo, S Suga, J. Phys. Chem. B 2005, 109, 15476.

[7] As recent examples: a) S. Zhang, A. Islam, X. Yang, C. Qin, K. Zhang, Y. Numata, H. Chen, L. Han, J. Mater. Chem. A 2013, 1, 4812; b) L. Han, A Islam, H. Chen, C. Malapaka, B. Chiranjeevi, S. Zhang, X. Yang, M. Yanagida, Energy Environ. Sci. 2012, 5, 6057; c) C.-M. Lan, H.-P. Wu, T.-Y. Pan, C.W. Chang, W.-S. Chao, C.-T. Chen, C.-L. Wang, C.-Y. Lin, E. W.-G. Diau, Energy Environ. Sci. 2012, 5, 6460.

[8] Y. Wu, W. Zhu, Chem. Soc. Rev. 2013, 42, 2039.

[9] J. Y. Li, A. Ziegler, G. Wegner, Chem. Eur. J. 2005, 11, 4450.

[10] Y.-S. Yen, C.-T. Lee, C.-Y. Hsu, H.-H. Chou, Y.-C. Chen, J. T. Lin, Chem. Asian J. 2013, 8, 809.

[11] a) W. Ying, J. Yang, M. Wielopolski, T. Moehl, J.-E. Moser, P. Comte, J. Hua, S. M. Zakeeruddin, H. Tian, M. Grätzel, Chem. Sci. 2014, 5, 206; b) K. Pei, Y. Wu, A. Islam, Q. Zhang, L. Han, H. Tian, W. Zhu, ACS Appl. Mater Interfaces 2013, 5, 4986; c) K. Pei, Y. Wu, W. Wu, Q. Zhang, B. Chen, H. Tian, W. Zhu, Chem. Eur. J. 2012, 18, 8190.

[12] W. Li, Y. Wu, Q. Zhang, H. Tian, W. Zhu, ACS Appl. Mater. Interfaces 2012, 4, 1822.

[13] F. Zhang, K.-J. Jiang, J.-H. Huang, C.-C. Yu, S.-G. Li, M.-G. Chen, L.-M. Yang, Y.-L. Song, J. Mater. Chem. A 2013, 1, 4858.

[14] a) M. Zhang, Y. Wang, M. Xu, W. Ma, R. Li, P. Wang, Energy Environ. Sci. 2013, 6, 2944; b) Y. Wu, M. Marszalek, S. M. Zakeeruddin, Q. Zhang, H.
Tian, M. Grätzel, W. Zhu, Energy Environ. Sci. 2012, 5, 8261; c) Y. Wu, X. Zhang, W. Li, Z.-S. Wang, H. Tian, W. Zhu, Adv. Energy Mater. 2012, 2, 149; d) H.-H. Chou, Y.-C. Chen, H.-J. Huang, T.-H. Lee, J. T. Lin, C. Tsai, K Chen, J. Mater. Chem. 2012, 22, 10929; e) S. Haid, M. Marszalek, A. Mishra, M. Wielopolski, J. Teuscher, J.-E. Moser, R. Humphry-Baker, S. M. Zakeeruddin, M. Grätzel, P. Bäuerle, Adv. Funct. Mater. 2012, 22, 1291; f) W. Zhu, Y. Wu, S. Wang, W. Li, X. Li, J. Chen, Z.-S. Wang, H. Tian, Adv. Funct. Mater. 2011, 21, 756; g) D. H. Lee, M. J. Lee, H. M. Song, B. J. Song, K. D. Seo, M. Pastore, C. Anselmi, S. Fantacci, F. De Angelis, M. K. Nazeeruddin, M. Grätzel, H. K. Kim, Dyes Pigm. 2011, 91, 192; h) J.-J. Kim, H. Choi, J.-W. Lee, M.-S. Kang, K. Song, S. O. Kang, J. Ko, J. Mater. Chem. 2008, 18, 5223; i) M. Velusamy, K. R. J. Thomas, J. T. Lin, Y.-C. Hsu, K.-C. Ho, Org. Lett. 2005, 7, 1899; j) X. Wang, J. Yang, H. Yu, F. Li, L. Fan, W. Sun, Y. Liu, Z. Y. Koh, J. Pan, W.-L. Yim, L. Yan, Q. Wang, Chem. Commun. 2014, 50, 3965.

[15] a) C. Teng, X. C. Yang, C. Yang, H. Tian, S. F. Li, X. Wang, A. Hagfeldt, L. Sun, J. Phys. Chem. C 2010, 114, 11305; b) J. Song, F. Zhang, C. Li, W. Liu, B. Li, Y. Huang, Z. Bo, J. Phys. Chem. C 2009, 113, 13391.

[16] H. Tian, X. Yang, R. Chen, R. Zhang, A. Hagfeldt, L. Sun, J. Phys. Chem. C 2008, 112, 11023.

[17] R. Grisorio, G. Allegretta, P. Mastrorilli, G. P. Suranna, Macromolecules 2011, 44, 7977.

[18] A. A. Gorman, M. A. Rodgers, Chem. Soc. Rev. 1981, 10, 205.

[19] H. D. Roth, Acc. Chem. Res. 1984, 17, 180.

[20] R. Grisorio, G. Allegretta, G. P. Suranna, P. Mastrorilli, A. Loiudice, A. Rizzo, M. Mazzeo, G. Gigli, J. Mater. Chem. 2012, 22, 19752.

[21] J.-L. Bredas, Mater. Horiz. 2014, 1, 17.

[22] a) K. Hara, Y. Dan-oh, C. Kasada, Y. Ohga, A. Shinpo, S. Suga, K. Sayama, H. Arakawa, Langmuir 2004, 20, 4205; b) Z.-S. Wang, Y. Cui, Y. Dan-oh, C. Kasada, A. Shinpo, K. Hara, J. Phys. Chem. C 2008, 112, 17011.

[23] J. Bisquert, J. Electroanal. Chem. 2010, 646, 43.

[24] J. Bisquert, F. Fabregat-Santiago, I. Mora-Sero', G. Garcia-Belmonte, S. Gimnez, J. Phys. Chem. 2009, 113, 17278.

[25] S. R. Raga, E. M. Barea, F. Fabregat-Santiago, J. Phys. Chem. Lett. 2012, 3, 1629.

[26] a) E. M. Barea, V. Gonzalez-Pedro, T. Ripolles-Sanchis, H.-P. Wu, L.-L. Li, C.Y. Yeh, E. W.-G. Diau, J. Bisquert, J. Phys. Chem. C 2011, 115, 10898; b) E. M. Barea, J. Ortiz, F. J. Paya, F. Fernandez-Lazaro, F. Fabregat-Santiago, A. Sastre-Santos, J. Bisquert, Energy Environ. Sci. 2010, 3, 1985.

[27] a) M. Pastore, E. Mosconi, F. De Angelis, J. Phys. Chem. C 2012, 116, 5965 ; b) X. Li, A. Reynal, P. Barnes, R. Humphry-Baker, S. M. Zakeeruddin, F. De Angelis, B. C. O'Regan, Phys. Chem. Chem. Phys. 2012, 14, 15421; c) X. Jiang, K. M. Karlsson, E. Gabrielsson, E. M. J. Johansson, M. Quintana, M. Karlsson, L. Sun, G. Boschloo, A. Hagfeldt, Adv. Funct. Mater. 2011, 21, 2944.

[28] C. M. Cardona, W. Li, A. E. Kaifer, D. Stockdale, G. C. Bazan, Adv. Mater. 2011, 23, 2367.

[29] Gaussian 09, revision D.01, M. J. Frisch, G. W. Trucks, H. B. Schlegel, G. E. Scuseria, M. A. Robb, J. R. Cheeseman, G. Scalmani, V. Barone, B. Mennucci, G. A. Petersson, H. Nakatsuji, M. Caricato, X. Li, H. P. Hratchian, A. F. Izmaylov, J. Bloino, G. Zheng, J. L. Sonnenberg, M. Hada, M. Ehara, K. Toyota, R. Fukuda, J. Hasegawa, M. Ishida, T. Nakajima, Y. Honda, O. Kitao, H. Nakai, T. Vreven, J. A. Montgomery, Jr., J. E. Peralta, F. Ogliaro, M. Bearpark, J. J. Heyd, E. Brothers, K. N. Kudin, V. N. Staroverov, R. Kobayashi, J. Normand, K. Raghavachari, A. Rendell, J. C. Burant, S. S. Iyengar, J. Tomasi, M. Cossi, N. Rega, J. M. Millam, M. Klene, J. E. Knox, J. B. Cross, V. Bakken, C. Adamo, J. Jaramillo, R. Gomperts, R. E. Stratmann, O. Yazyev, A. J. Austin, R. Cammi, C. Pomelli, J. W. Ochterski, R. L. Martin, K. Morokuma, V. G. Zakrzewski, G. A. Voth, P. Salvador, J. J. Dannenberg, S. Dapprich, A. D. Daniels, O. Farkas, J. B. Foresman, J. V. Ortiz, J. Cioslowski, D. J. Fox, Gaussian, Inc., Wallingford CT, 2009.

Received: March 11, 2014

Published online on $\square$ uI, 0000 


\section{FULL PAPERS}

R. Grisorio, L. De Marco, * R. Agosta,

R. lacobellis, R. Giannuzzi, M. Manca,

P. Mastrorilli, G. Gigli, G. P. Suranna*

Enhancing Dye-Sensitized Solar Cell Performances by Molecular Engineering: Highly Efficient $\pi$ Extended Organic Sensitizers

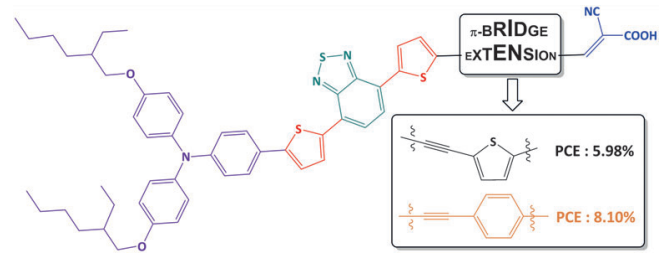

Can I have an extension please? Two new $\pi$-extended $D-A-\pi-A$ dyes are synthesized for application in dye-sensitized solar cells (DSSCs). The introduction of an ethynylene-phenylene moiety in the $\pi$-bridge leads to remark- ably higher efficiency in DSSCs compared to the sensitizer with the ethynylene-thienylene spacer due to higher electron injection, inhibition of back electron-transfer as well as dark current. 